\title{
BMJ Global Health Integrated prevention and management of non-communicable diseases, including musculoskeletal health: a systematic policy analysis among OECD countries
}

To cite: Briggs AM, Persaud JG, Deverell ML, et al. Integrated prevention and management of non-communicable diseases, including musculoskeletal health: a systematic policy analysis among OECD countries. BMJ Global Health 2019;4:e001806. doi:10.1136/ bmjgh-2019-001806

Handling editor Soumyadeep Bhaumik

- Additional material is published online only. To view please visit the journal online (http://dx.doi.org/10.1136/ bmjgh-2019-001806).

Received 4 July 2019 Revised 5 August 2019 Accepted 10 August 2019

Check for updates

(c) Author(s) (or their employer(s)) 2019. Re-use permitted under CC BY-NC. No commercial re-use. See rights and permissions. Published by BMJ.

For numbered affiliations see end of article.

Correspondence to Professor Andrew M Briggs; a.briggs@curtin.edu.au

\section{ABSTRACT}

Introduction Development and implementation of appropriate health policy is essential to address the rising global burden of non-communicable diseases (NCDs). The aim of this study was to evaluate existing health policies for integrated prevention/management of NCDs among Member States of the Organisation for Economic Co-operation and Development (OECD). We sought to describe policies' aims and strategies to achieve those aims, and evaluate extent of integration of musculoskeletal conditions as a leading cause of global morbidity.

Methods Policies submitted by OECD Member States in response to a World Health Organization (WHO) NCD Capacity Survey were extracted from the WHO document clearing-house and analysed following a standard protocol. Policies were eligible for inclusion when they described an integrated approach to prevention/management of NCDs. Internal validity was evaluated using a standard instrument (sum score: 0-14; higher scores indicate better quality). Quantitative data were expressed as frequencies, while text data were content-analysed and meta-synthesised using standardised methods.

Results After removal of duplicates and screening, 44 policies from 30 OECD Member States were included. Three key themes emerged to describe the general aims of included policies: system strengthening approaches; improved service delivery; and better population health Whereas the policies of most countries covered cancer (83.3\%), cardiovascular disease (76.6\%), diabetes/ endocrine disorders $(76.6 \%)$, respiratory conditions $(63.3 \%)$ and mental health conditions $(63.3 \%)$, only half the countries included musculoskeletal health and pain (50.0\%) as explicit foci. General strategies were outlined in $42(95.5 \%)$ policies—all were relevant to musculoskeletal health in 12 policies, some relevant in 27 policies and none relevant in three policies. Three key themes described the strategies: general principles for people-centred NCD prevention/management; enhanced service delivery; and system strengthening approaches. Internal validity sum scores ranged from 0 to 13 ; mean: 7.6 (95\% $\mathrm{Cl} 6.5$ to 8.7$)$.

\section{Key questions}

What is already known?

- Health policy is recognised as essential to build capacity in health systems to respond to the increasing burden associated with non-communicable diseases (NCDs).

- Although musculoskeletal conditions and persistent pain are leading causes of global morbidity, global action plans and monitoring frameworks for NCDs have historically not explicitly included these conditions.

What are the new findings?

- Health policies for integrated prevention/management of NCDs among OECD countries typically address NCDs closely aligned to mortality, in alignment with target 3.4 of the Sustainable Development Goals.

- Musculoskeletal health conditions and persistent pain feature less prominently than other NCDs.

- The aims and strategies for integrated managemen of NCDs among OECD Member States align with the WHO System Building Blocks and Integrated PeopleCentred Health Services frameworks.

What do the new findings imply?

- There is close alignment between NCD global action plans and monitoring frameworks and the NCD policy foci of OECD Member States.

- While many general strategies outlined in the included policies are relevant to addressing musculoskeletal health, without an explicit focus in national policy and global strategies meaningful improvements in global morbidity may not be achievable.

Conclusion Relative to other NCDs, musculoskeletal health did not feature as prominently, although many general prevention/management strategies were relevant to musculoskeletal health improvement. 


\section{INTRODUCTION}

Non-communicable diseases (NCDs) represent one of the most important and urgent threats to human health globally, ${ }^{1-3}$ with a disproportionate and increasing burden experienced by older people and those in low-income and middle-income countries (LMICs). The burden of disease attributed to NCDs now far outweighs that associated with communicable, maternal, neonatal and nutritional deficiency diseases in most countries. ${ }^{4}$ The impacts of NCDs are significant and wide-reaching. These include direct health consequences (such as premature death, reduced functional ability, impaired quality of life) and also dramatic social and economic sequelae that impact human capital and prosperity leading to poverty and threats to achieving targets of the Sustainable Development Goals (SDGs). ${ }^{35-7}$

On a background of global population ageing and an increasing prevalence of risk factors for the development of NCDs (eg, harmful use of alcohol and tobacco, physical inactivity, poor diet, and pollution), the magnitude of the burden of disease attributed to NCDs is expected to increase and further threaten the sustainability of health systems. ${ }^{89}$ In the most recent analysis of the Global Burden of Disease Study, NCDs accounted for the majority $(62 \%)$ of total burden of disease globally, expressed as disability-adjusted life years (DALYs), representing an increase of $16 \%$ from 2007 to $2017 .{ }^{4}$ NCDs as a major contributor to total disease burden was observed across all economies. As a disaggregated DALY burden, NCDs accounted for the greatest proportion of deaths in $2017(73 \%)$, reflecting an increase of 23\% from 2007 to $2017^{10}$ and $80 \%$ of the total years lived with disability (YLDs), or morbidity burden, in $2017 .{ }^{9}$ Critically, the number YLDs attributed to NCDs from 1990 to 2017 has risen by $61 \% .^{9}$ In particular, musculoskeletal conditions are a major contributor to the NCD disability burden, particularly in association with ageing. ${ }^{9} 1112$ YLDs for musculoskeletal conditions have risen by $20 \%$ from 2007 to 2017 and low back pain remains the single leading cause of global disability since $1990 .{ }^{9}$ Recent systematic review evidence suggests that a third to a half of the population in the UK lives with chronic pain, the majority of which is musculoskeletal in aetiology, ${ }^{13}$ mirroring trends in LMICs. ${ }^{14}$ Despite the identified burden of disease of musculoskeletal pain, and evidence of pain as a key determinant of disability, ${ }^{15}$ historically it has not been integrated into NCD prevention and management policy or strategy in most countries, or by the World Health Organization (WHO). ${ }^{1116}$

Against this backdrop, health systems globally are often ill-equipped to effectively address prevention and management of NCDs. ${ }^{261718}$ Urgent attention to system strengthening approaches to more effectively address prevention and management of NCDs and support healthy ageing, is therefore, well justified. ${ }^{6}{ }^{19}$ While strengthening approaches should be nationally-specific, global leadership and support from high-income economies, such as Member States of the Organisation for
Economic Co-operation and Development (OECD), is important.

However, multiple barriers have been identified as limiting progress in addressing the burden of NCDs: political will, appropriate policy, commercial forces, inadequate technical and operational capacity, insufficient financing, inadequate action to the social determinants of health and lack of accountability. ${ }^{20}$ The Lancet Global Health Commission argues that health system strengthening approaches that include formulation of national policy to prioritise prevention and management of NCDs is essential, ${ }^{2}$ mirroring objectives of the WHO global action plan $^{21}$ and other calls for urgent policy formulation. ${ }^{11} 22-25$ Despite the identified burden of disease, political action on NCDs has been criticised and deemed inadequate to ensure global health security into the future and achievement of the 2030 targets for SDG 3.4 will not be achieved. ${ }^{1622}$

Since NCDs often co-occur, particularly in the context of ageing, ${ }^{26}$ and many share common behavioural and environmental risk factors, system reform for NCDs should typically be approached in an integrated manner at both system and service levels, rather than in disease-specific siloes. ${ }^{18}$ The WHO has provided guidance, or 'best buys' ${ }^{27}$ on how to prevent and manage NCDs as part of the Global Action Plan for the Prevention and Control of NCDs 2013-2020. ${ }^{21}$ This Action Plan and the targets for SDG 3.4 are largely aligned to mortality reduction for cancer, diabetes, cardiovascular disease and lung disease. While imperative, this focus inadequately considers the profound morbidity burden associated with NCDs, especially musculoskeletal conditions, and contemporary global health estimate data pointing to an increasing life expectancy associated with poor health. ${ }^{4}$

The aim of this study was to evaluate health policies for integrated prevention/management of NCDs among Member States of the OECD. Specifically, we sought to describe the aims, and strategies to achieve those aims, among policies and evaluate the extent to which musculoskeletal conditions were integrated. We limited our analysis to OECD Member States as a starting point for this research, recognising that these nations are considered policy leaders and work to support global social and economic development.

\section{METHODS \\ Design}

Systematic document review and data analysis of health policies on integrated NCD prevention or management of OECD Member States that participated in a WHO NCD Country Capacity Survey. ${ }^{22}$

\section{Patient and public involvement}

Patients were not directly involved in the design or execution of the research. The research was co-designed with representatives from patient advocacy organisations (JGP, $\mathrm{AC})$ and government (JGP, MLD, YS) . 


\section{Eligibility for inclusion}

Health policies of the 36 OCED Member States that reported on integrated NCD prevention/management and were submitted to WHO between 2015 and 2017 as part of a WHO NCD Country Capacity Survey were eligible for inclusion. We defined 'policy document' as any national or regional health policy, strategy or action plan submitted by a country in response a WHO NCD Country Capacity Survey, consistent with aligned research. ${ }^{28}$

\section{Document selection}

A document repository of Member States' policies, strategies and action plans for NCDs and their risk factors, NCD clinical guidelines, and NCD legislation and regulation, submitted in response to periodic WHO NCD Country Capacity Survey was created by the WHO in 2016 (https://extranet.who.int/ncdccs/documents/db). We used this document clearing-house to identify and download the relevant policy document(s) for each country. Where documents were not available from the clearing-house for some countries (Austria, Finland, Greece, Luxembourg, New Zealand, Turkey), the WHO secretariat was contacted in 2018 to confirm that no submissions were made from these countries. We confirmed that Finland, Greece, Luxembourg and New Zealand had not made submissions, while policies were under development (in 2017) for Austria and Turkey. We therefore undertook a desktop internet search for relevant policies from the Ministries of Health of Austria (in German) and Turkey (in English) and identified the relevant Turkish policy. No specific policy for NCD prevention or management was identified for Austria, other than 2013 action plans for nutrition and physical activity. ${ }^{29}{ }^{30}$ Since policies were not under development for Finland, Greece, Luxembourg or New Zealand, internet searches were not undertaken for these nations, although we recognise that potentially suitable policies may exist.

\section{Document review and data extraction}

A multidisciplinary and multilingual team of 13 reviewers was assembled to review documents and extract data (five from Australia; five from Western Europe; one from Eastern Europe; one from Asia and one from North America). For those documents published in a language outside the language competencies of the review team, online translation software was used to translate the text to English (https://www.onlinedoctranslator.com/en/).

A standardised data extraction template was developed to ensure a consistent approach to document reviews and data extraction (online supplementary file 1). The data extraction template collected data on: publication information; vision and scope of the policy; health conditions explicitly included; strategies/actions proposed to achieve the objectives/aims of the policy; and the extent of explicit integration of musculoskeletal conditions, mobility/functional impairment or persistent non-cancer pain within the scope of prevention/management for NCDs. The template was initially piloted on nine policies across seven countries between four reviewers (September-October 2018), before being revised and piloted again on two policies from one country by one reviewer (November 2018). The main review period was December 2018 to April 2019, with each reviewer assigned to one or more countries based on their language skills. A review protocol document was also prepared after the pilot phase, to accompany the data extraction sheet and guide reviewers in standardised document review and data extraction tasks.

\section{Quality appraisal}

A quality appraisal (internal validity) of each policy document was undertaken as a component of the review task. A quality appraisal tool using assessment criteria and a response scale established and used previously for evaluation of chronic disease policies was used. ${ }^{31}$ The tool was based on important evaluation criteria previously identified in the literature ${ }^{31-33}$ It consisted of seven items covering seven domains reflecting best-practice policy development (background and case for change; goals; resource considerations; monitoring and evaluation; public opportunity; obligations; and potential for public health impact) and rated on a 3-point nominal response scale (scored from 0 to 2; total score range $0-14$ ). The inter-rater reliability of the tool was assessed across nine policies in the first pilot phase. A kappa $(k)$ statistic was computed for each domain, with 6 out of 7 categorised as fair/good $(k=0.4-0.75)$ to excellent $(k>0.75)$, based on thresholds recommended by Fleiss. ${ }^{34}$ The domain 'goals' had poor reliability $(k<0.4)$. The inter-rater reliability of sum scores was, however, high, expressed as an intra-class correlation coefficient (ICC); ICC: 0.91 (95\% CI 0.68 to $0.98)$.

\section{Data analysis}

Reviewers submitted their completed data extraction sheets to a project officer who quality-checked the submissions, based on a quality checklist established a priori. Simple (short-text) data were recorded verbatim, while content analysis was undertaken to analyse extensive text responses, ${ }^{35}$ using standard methods for inductive coding and meta-synthesis. ${ }^{36}{ }^{37}$ Content analysis was applied to the following data fields: (1) Aim/vision of the policy. (2) Strategies to achieve the policy aims/objectives. (3) Relevance of the strategies to the prevention/management of musculoskeletal health.

For each of these three data fields, a five-step process was undertaken. First, a primary analyst (AMB) inductively developed a coding framework (first-order codes) based on the provided responses. Second, the coding framework was verified independently by two reviewers (EMGH, HS) using a $20 \%$ subset of responses, with discrepancies resolved through consensus. Third, the primary analyst coded each response against the coding framework. Fourth, coding was verified independently by two reviewers (EMGH, HS) using a $20 \%$ subset of responses, with discrepancies resolved through 
consensus. Discordance in coding ranged from $0 \%$ to $7 \%$ across questions. Finally, an interdisciplinary group (AMB, JGP, MLD, EMGH, HS) representing clinicians, researchers, civil society represenatives and policy makers met and familiarised themselves with the derived coding framework. These initial codes were then iteratively and inductively organised into consensus-based descriptive subthemes. We then derived new, higher-order themes that extended beyond the initial coding framework. Findings were linked back to the research questions to ensure relevance and appropriate contextualisation for a narratively reported meta-synthesis. Frequencies of first-order codes were calculated to provide an indication of overall weighting.

\section{RESULTS}

\section{Overview of included policies}

\section{Document selection}

We identified 48 policies for inclusion across 31 OECD Member States from the WHO document clearing-house (see PRISMA-aligned flow chart, online supplementary file 2). No policies were included for five OECD Member States (Austria, Finland, Greece, Luxembourg and New Zealand). An additional six policies were identified through other means, including: one document for each of Portugal, ${ }^{38}$ Turkey ${ }^{39}$ and the Republic of Korea, ${ }^{40}$ identified through desktop internet searches (as these documents were not available in the WHO database or were outdated); and, based on advice from Public Health Canada, three documents linked to the primary Canadian policy, ${ }^{41-43}$ 'Canadian Integrated Strategy on Healthy Living and Chronic Disease' $(\mathrm{N}=54) .{ }^{44}$ At screening and eligibility assessment, 10 policy documents were excluded: 6 duplicates and 4 did not meet the inclusion criteria (Belgium, Canada, Israel, Italy; online supplementary file 2). Consequently, 44 policies from 30 OECD Member States were included in the final review. ${ }^{38-81}$

\section{Policy characteristics and aims}

A summary of included policies is provided in table 1 . Policies were regionally represented as 1 (2.3\%) from Oceania, $28(63.6 \%)$ from the European Union, 5 (11.4\%) from Europe, 5 (11.4\%) from North America, 1 (2.3\%) from South America, 1 (2.3\%) from Central America and 3 (6.8\%) from Asia. Forty-two (95.4\%) polices originated from high-income economies and two $(4.6 \%)$ from upper-income middle-income economies. All policies were national in reach; 13 (29.5\%) explicitly aligned with the WHO Global Action Plan ${ }^{21}$; and 11 $(25 \%)$ focused on NCD prevention only, $1(2.3 \%)$ on NCD management only, and $32(72.7 \%)$ on NCD prevention and management.

The purpose/aims of included policies (table 1) were summarised with three overarching themes, supported by a range of subthemes and linked to 22 first-order codes (online supplementary file 3 ). These are described in the meta-synthesis below.

\section{System strengthening}

Policies outlined a system-strengthening focus that included aspects of governance (such as the creation of disease-specific models of care and public policy), financing to achieve health service sustainability and building workforce capacity. A number of policies also included a focus on building emergency and disaster response capacity. Expanding the reach of health services through improved coverage and access to minimise inequality due to socioeconomic or geographical factors, were also identified. Some policies identified population health monitoring as a focus.

\section{Service delivery}

Policies cited improvement in health service delivery as a key focus through effective, efficient and comprehensive management approaches for NCDs, including addressing multimorbidity. Quality in service delivery and support for integrated care, active self-management and innovation in service delivery were identified as common aims.

\section{Population health}

Policies aimed to target risk factors for poor health, to support screening and to promote healthy lifestyles across the life course as a means to improve physical and mental health and functional ability. Specific policy foci included a reduction in use and harms related to substance abuse, decreasing the incidence and prevalence of overweight and obesity, and improving population-level physical activity. Policies aimed to reduce the impact of NCDs by reducing incidence of disease (NCDs and communicable diseases) and premature mortality and injury, thereby improving the quality of life of the population. Environmental factors influencing health were also cited, including food and workplace safety.

\section{Integration of musculoskeletal health, persistent pain and mobility/functional ability in NCD health policies}

Figure 1 illustrates the conditions (health states) explicitly stated as being covered by the policies across nations, while table 2 summarises this detail by policy. Whereas the polices of most countries covered cancer $(83.3 \%)$, cardiovascular disease $(76.6 \%)$, diabetes/endocrine disorders $(76.6 \%)$, respiratory conditions $(63.3 \%)$ and mental health conditions (63.3\%), only half the countries included musculoskeletal health and pain $(50.0 \%)$ as conditions covered within the policies. Five $(16.7 \%)$ countries had policies that included any chronic health conditions. Among the 41 (93.2\%) policies of 30 countries that included a background commentary, 23 (56.1\%) mentioned musculoskeletal health, pain or mobility/ functional ability in some way. Within the specific context of prevention and/or management of NCDs, 23 (52.3\%) policies of $19(63.3 \%)$ countries referred explicitly to musculoskeletal health, pain or mobility/functional ability, including: $20(45.4 \%)$ to musculoskeletal health, $5(11.4 \%)$ to pain and $11(25.0 \%)$ to mobility/functional 
Table 1 Characteristics of included policies

\begin{tabular}{|c|c|c|c|c|c|}
\hline $\begin{array}{l}\text { Nation } \\
\text { (income } \\
\text { bandt) }\end{array}$ & $\begin{array}{l}\text { Policy title (year of publication; } \\
\text { classification } \ddagger \text { ) }\end{array}$ & Time span & $\begin{array}{l}\text { Explicit } \\
\text { alignment } \\
\text { with the } \\
\text { WHO Action } \\
\text { Plan§ (yes/ } \\
\text { no) }\end{array}$ & $\begin{array}{l}\text { Focus (NCD } \\
\text { prevention; } \\
\text { NCD } \\
\text { management; } \\
\text { both) }\end{array}$ & Purpose, aim or vision \\
\hline $\begin{array}{l}\text { Australia } \\
\text { (high) }\end{array}$ & $\begin{array}{l}\text { National Strategic Framework for Chronic } \\
\text { Conditions }(2017 \text {; primary })^{\star 45}\end{array}$ & $2017-2025$ & Yes & $\begin{array}{l}\text { Prevention } \\
\text { +management }\end{array}$ & $\begin{array}{l}\text { All Australians live healthier lives through effective } \\
\text { prevention and management of chronic conditions. }\end{array}$ \\
\hline $\begin{array}{l}\text { Belgium } \\
\text { (high) }\end{array}$ & $\begin{array}{l}\text { Chronic Disease Plan. Integrated Health } \\
\text { Services for Better Health (2015; primary) }\end{array}$ & n.s. & No & $\begin{array}{l}\text { Prevention } \\
\text { +management }\end{array}$ & $\begin{array}{l}\text { To support the improvement of the quality of life of the } \\
\text { population, in particular people suffering from multiple } \\
\text { chronic conditions and ensure that they can live better } \\
\text { in their own environment (family, school, work) and the } \\
\text { community, and can engage in active self-management } \\
\text { of their own health. }\end{array}$ \\
\hline
\end{tabular}

\begin{tabular}{|c|c|c|c|c|c|}
\hline \multirow[t]{4}{*}{$\begin{array}{l}\text { Canada } \\
\text { (high) }\end{array}$} & $\begin{array}{l}\text { Integrated Strategy on Healthy Living and } \\
\text { Chronic Disease }(2005 \text {; secondary })^{\star 44}\end{array}$ & n.s & No & $\begin{array}{l}\text { Prevention } \\
\text { +management }\end{array}$ & $\begin{array}{l}\text { To provide a framework for the federal government } \\
\text { to promote the health of Canadians and reduce the } \\
\text { impact of chronic disease in Canada. }\end{array}$ \\
\hline & $\begin{array}{l}\text { Canada's Tobacco Strategy (2018; } \\
\text { secondary) }\end{array}$ & 2018-2035 & No & Prevention & To achieve a target of $<5 \%$ tobacco use by 2035 . \\
\hline & $\begin{array}{l}\text { Curbing Childhood Obesity: A Federal, } \\
\text { Provincial and Territorial Framework for } \\
\text { Action to Promote Healthy Weights (2010; } \\
\text { primary) }\end{array}$ & n.s. & No & Prevention & $\begin{array}{l}\text { Canada is a country that creates and maintains the } \\
\text { conditions for healthy weights so that children can } \\
\text { have the healthiest possible lives. }\end{array}$ \\
\hline & $\begin{array}{l}\text { Let's get moving: A common vision for } \\
\text { increasing physical activity and reducing } \\
\text { sedentary living in Canada (2018; primary) }\end{array}$ & n.s. & No & Prevention & $\begin{array}{l}\text { A Canada where all Canadians move more and sit less, } \\
\text { more often. }\end{array}$ \\
\hline $\begin{array}{l}\text { Chile } \\
\text { (high) }\end{array}$ & $\begin{array}{l}\text { National Health Strategy to Complete the } \\
\text { Health Objectives of the Decade (2011; } \\
\text { primary })^{47}\end{array}$ & 2011-2020 & No & $\begin{array}{l}\text { Prevention } \\
\text { +management }\end{array}$ & $\begin{array}{l}\text { Reduce the impact of chronic communicable and non- } \\
\text { communicable disease, traffic accidents and family } \\
\text { violence, through actions, screening and prevention } \\
\text { strategies, improved health coverage and treatment; } \\
\text { target risk factors for NCDs; enhance workplace } \\
\text { health and safety and food safety; strengthen the } \\
\text { public health system and health workforce; and build } \\
\text { preparedness for emergency and disaster relief. }\end{array}$ \\
\hline \multirow[t]{2}{*}{$\begin{array}{l}\text { Czech } \\
\text { Republic } \\
\text { (high) }\end{array}$} & $\begin{array}{l}\text { HEALTH } 2020 \text { - National Strategy for Health } \\
\text { Protection and Promotion and Disease } \\
\text { Prevention (2014; primary) }{ }^{\star 48}\end{array}$ & $2014-2020$ & No & $\begin{array}{l}\text { Prevention } \\
\text { +management }\end{array}$ & $\begin{array}{l}\text { Stabilise the system of disease prevention, health } \\
\text { protection and promotion and to initiate efficient } \\
\text { mechanisms to improve health of the population, } \\
\text { sustainable in the long term. }\end{array}$ \\
\hline & $\begin{array}{l}\text { Long-term programme of improving the } \\
\text { health status of the population of the Czech } \\
\text { Republic - Health for All in the } 21 \text { st Century } \\
(2002 \text {; primary) })^{\star \star 49}\end{array}$ & n.s. & No & $\begin{array}{l}\text { Prevention } \\
\text { +management }\end{array}$ & $\begin{array}{l}\text { Protect human health and development over the life } \\
\text { course and reduce the incidence of diseases and } \\
\text { injuries and limit suffering. }\end{array}$ \\
\hline \multirow[t]{2}{*}{$\begin{array}{l}\text { Denmark } \\
\text { (high) }\end{array}$} & $\begin{array}{l}\text { Recommendations for preventative services } \\
\text { for citizens with chronic diseases }(2016 \text {; } \\
\text { primary })^{50}\end{array}$ & n.s. & No & $\begin{array}{l}\text { Prevention } \\
\text { +management }\end{array}$ & $\begin{array}{l}\text { Guide how services in the municipalities can } \\
\text { implement important preventative measures in the } \\
\text { best possible way, so citizens all over the country will } \\
\text { receive high-quality services for prevention of chronic } \\
\text { diseases. }\end{array}$ \\
\hline & $\begin{array}{l}\text { Care pathways for chronic diseases - the } \\
\text { generic model (2012; primary) }\end{array}$ & n.s. & No & $\begin{array}{l}\text { Prevention } \\
\text { +management }\end{array}$ & $\begin{array}{l}\text { To present a generic model of care to use as a basis } \\
\text { for creating other (disease-specific) care pathways. }\end{array}$ \\
\hline $\begin{array}{l}\text { Estonia } \\
\text { (high) }\end{array}$ & $\begin{array}{l}\text { National Health Plan 2009-2020 (2012; } \\
\text { primary) }\end{array}$ & $2009-2020$ & No & Management & $\begin{array}{l}\text { A longer health-adjusted life expectancy by decreasing } \\
\text { premature mortality and illnesses. }\end{array}$ \\
\hline \multirow[t]{2}{*}{$\begin{array}{l}\text { France } \\
\text { (high) }\end{array}$} & $\begin{array}{l}\text { Laws Official Journal of the French Republic } \\
\text { of January 27th, } 2016 \text { : Law no 2016-41, } \\
\text { January 26th, } 2016 \text { of the Modernisation } \\
\text { of Our Health System (1). Keynote Title: } \\
\text { Mobilising Health System Members Around } \\
\text { a Shared Strategy (2016; primary) }\end{array}$ & n.s. & No & $\begin{array}{l}\text { Prevention } \\
\text { +management }\end{array}$ & $\begin{array}{l}\text { To mobilise health system members around a shared } \\
\text { (health) strategy. }\end{array}$ \\
\hline & $\begin{array}{l}\text { National Health Strategy: Roadmap (2013; } \\
\text { primary) }^{54}\end{array}$ & n.s. & No & $\begin{array}{l}\text { Prevention } \\
\text { +management }\end{array}$ & $\begin{array}{l}\text { To address growing social and geographical } \\
\text { inequalities which limit access to healthcare in France. }\end{array}$ \\
\hline $\begin{array}{l}\text { Germany } \\
\text { (high) }\end{array}$ & $\begin{array}{l}\text { IN FORM: Germany's initiative for healthy } \\
\text { nutrition (diet) and more physical activity. } \\
\text { National action plan for prevention of } \\
\text { malnutrition, lack of physical activity } \\
\text { overweight and associated diseases (2014; }_{\text {primary) }}^{55}\end{array}$ & n.s. & Yes & $\begin{array}{l}\text { Prevention } \\
\text { +management }\end{array}$ & $\begin{array}{l}\text { To improve the nutrition and physical activity behaviour } \\
\text { in Germany in a sustainable way, such that: adults live } \\
\text { healthier, children grow up healthier and benefit from } \\
\text { a higher quality of life and an increased performance } \\
\text { in their education, profession and private life; and } \\
\text { diseases that are caused by an unhealthy lifestyle will } \\
\text { decline. }\end{array}$ \\
\hline
\end{tabular}

Continued 
Table 1 Continued

\begin{tabular}{|c|c|c|c|}
\hline $\begin{array}{l}\text { Nation } \\
\text { (income } \\
\text { bandf) }\end{array}$ & $\begin{array}{l}\text { Policy title (year of publication; } \\
\text { classification } \ddagger \text { ) }\end{array}$ & Time span & $\begin{array}{l}\text { Explicit } \\
\text { alignment } \\
\text { with the } \\
\text { WHO Action } \\
\text { Plan§ (yes/ } \\
\text { no) }\end{array}$ \\
\hline $\begin{array}{l}\text { Hungary } \\
\text { (high) }\end{array}$ & $\begin{array}{l}\text { 'Healthy Hungary 2014-2020'-Health } \\
\text { Sector Strategy (2015; primary) }\end{array}$ & 2014-2020 & No \\
\hline
\end{tabular}

Focus (NCD

prevention;

NCD

both)

Purpose, aim or vision

Prevention

+management

To improve the health of Hungarians through different interventions (prevention, rehabilitation) and through further improvement to the whole healthcare system across sectors with a focus on responsible and cooperative citizen participation.

\begin{tabular}{|c|c|c|c|c|}
\hline $\begin{array}{l}\text { Iceland } \\
\text { (high) }\end{array}$ & $\begin{array}{l}\text { Public health policy and actions to } \\
\text { encourage a healthier society - with } \\
\text { emphasis on children and adolescents } \\
\text { under } 18 \text { years of age (2016; primary) }\end{array}$ & 2016-2018 & No & $\begin{array}{l}\text { Prevention } \\
\text { +management }\end{array}$ \\
\hline $\begin{array}{l}\text { Ireland } \\
\text { (high) }\end{array}$ & $\begin{array}{l}\text { Tackling Chronic Disease: A Policy } \\
\text { Framework for the Management of Chronic } \\
\text { Diseases }\left(2008 \text {; primary) }{ }^{\star 58}\right.\end{array}$ & n.s. & No & $\begin{array}{l}\text { Prevention } \\
\text { +management }\end{array}$ \\
\hline
\end{tabular}

Iceland will be one of the healthiest nations worldwide by 2030 .

Healthy Ireland: A framework for improved

2013-2025 No

health and well-being 2013-2025 (2013; primary) ${ }^{\star 59}$

\begin{tabular}{|c|c|c|c|c|c|}
\hline \multirow[t]{3}{*}{$\begin{array}{l}\text { Italy } \\
\text { (high) }\end{array}$} & 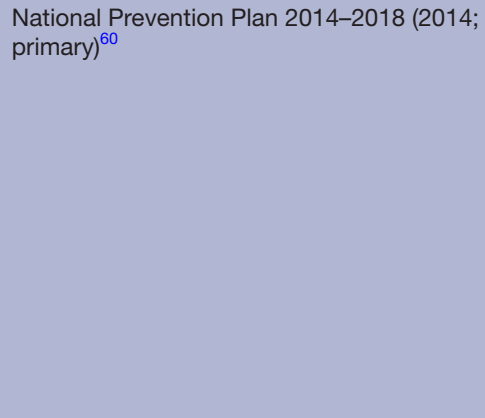 & 2014-2018 & Yes & Prevention & $\begin{array}{l}\text { To establish the crucial role of health promotion } \\
\text { and prevention as factors of social development } \\
\text { and welfare sustainability, in light of demographic } \\
\text { changes; adopt a public health approach that will } \\
\text { guarantee equality and contrast disparities; express } \\
\text { the cultural vision in public health values, objectives } \\
\text { and methods; base health prevention, promotion } \\
\text { and care interventions on best effective evidence, } \\
\text { implemented with equality and planned to reduce } \\
\text { disparities; accept and manage the challenge of cost- } \\
\text { effective interventions, innovation and governance; } \\
\text { and develop competence in professionals, people and } \\
\text { individuals aiming at an appropriate and responsible } \\
\text { use of available resources. }\end{array}$ \\
\hline & National Chronicity Plan (2016; primary) ${ }^{61}$ & n.s. & Yes & $\begin{array}{l}\text { Prevention } \\
\text { +management }\end{array}$ & $\begin{array}{l}\text { To contribute to the improvement of health protection } \\
\text { for chronically ill people, reducing the burden on the } \\
\text { individual, on his/her family and on the social context, } \\
\text { improving the quality of life, making health services } \\
\text { more effective and efficient in terms of prevention and } \\
\text { assistance and assuring a higher harmonisation and } \\
\text { equity for citizens' access. This will be achieved by } \\
\text { identifying a common strategy aiming at promoting } \\
\text { a unified approach to interventions centred on the } \\
\text { individual and oriented towards a better service } \\
\text { organisation and responsibilities of all the service- } \\
\text { providing actors. }\end{array}$ \\
\hline & $\begin{array}{l}\text { Gaining Health: Making healthy choices } \\
\text { easy (2008; primary })^{62}\end{array}$ & n.s. & No & Prevention & $\begin{array}{l}\text { To make healthy life choices easier for Italians and to } \\
\text { promote information campaigns aimed at changing } \\
\text { unhelpful behaviours, which contribute to causing non- } \\
\text { communicable diseases of a major epidemiological } \\
\text { significance. }\end{array}$ \\
\hline $\begin{array}{l}\text { Japan } \\
\text { (high) }\end{array}$ & $\begin{array}{l}\text { Health Japan } 21 \text { (the second term) (2012; } \\
\text { primary) }{ }^{63}\end{array}$ & 2013-2022 & No & Prevention & $\begin{array}{l}\text { To improve lifestyles and the social environment; to } \\
\text { enable all citizens from infancy to older adulthood to } \\
\text { have hope and meaning for living; to achieve a vibrant } \\
\text { society with healthy and spiritually rich lives according } \\
\text { to life stages; and to improve sustainability of the } \\
\text { social security system. }\end{array}$ \\
\hline \multirow[t]{2}{*}{$\begin{array}{l}\text { Republic of } \\
\text { Korea } \\
\text { (high) }\end{array}$} & $\begin{array}{l}\text { National Health Plan } 2020 \text { in Korea (2011; } \\
\text { secondary) }\end{array}$ & $2011-2020$ & No & $\begin{array}{l}\text { Prevention } \\
\text { +management }\end{array}$ & $\begin{array}{l}\text { To create a healthy world all people can enjoy together } \\
\text { through an extension of healthy life expectancy, an } \\
\text { improvement in health equity and monitoring of health } \\
\text { trends. }\end{array}$ \\
\hline & $\begin{array}{l}\text { The Third National Health Promotion Plan } \\
(2011-2020) \text { (2011; primary) }\end{array}$ & 2011-2020 & Yes & $\begin{array}{l}\text { Prevention } \\
\text { +management }\end{array}$ & $\begin{array}{l}\text { To establish national policies aimed at enhancing } \\
\text { the health of individuals and groups through health } \\
\text { education, disease prevention, nutrition improvement } \\
\text { and the practice of healthy lifestyles. }\end{array}$ \\
\hline
\end{tabular}

Continued 


\section{Table 1 Continued}

\begin{tabular}{|c|c|c|c|c|c|}
\hline $\begin{array}{l}\text { Nation } \\
\text { (income } \\
\text { bandt) }\end{array}$ & $\begin{array}{l}\text { Policy title (year of publication; } \\
\text { classification‡) }\end{array}$ & Time span & $\begin{array}{l}\text { Explicit } \\
\text { alignment } \\
\text { with the } \\
\text { WHO Action } \\
\text { Plan§ (yes/ } \\
\text { no) }\end{array}$ & $\begin{array}{l}\text { Focus (NCD } \\
\text { prevention; } \\
\text { NCD } \\
\text { management; } \\
\text { both) }\end{array}$ & Purpose, aim or vision \\
\hline $\begin{array}{l}\text { Latvia } \\
\text { (high) }\end{array}$ & $\begin{array}{l}\text { Public Health Guidelines 2014-2020 (2014; } \\
\text { primary) }{ }^{* \star 65}\end{array}$ & 2014-2020 & Yes & $\begin{array}{l}\text { Prevention } \\
\text { +management }\end{array}$ & $\begin{array}{l}\text { To increase the lived healthy life years of the Latvian } \\
\text { population and prevent premature death through } \\
\text { maintaining, improving and restoring health. }\end{array}$ \\
\hline \multirow[t]{3}{*}{$\begin{array}{l}\text { Lithuania } \\
\text { (high) }\end{array}$} & $\begin{array}{l}\text { Seimas of the Republic of Lithuania } \\
\text { Resolution No XII-964 of Approval of the } \\
\text { Lithuanian Health Strategy 2014-2025 } \\
(2014 \text {; primary })^{* 66}\end{array}$ & 2014-2025 & No & Prevention & $\begin{array}{l}\text { The attainment of improved health of the Lithuanian } \\
\text { population by } 2025 \text { as well as longer life and reduced } \\
\text { health inequities. }\end{array}$ \\
\hline & $\begin{array}{l}\text { The } 2014-2020 \text { National Programme } \\
\text { Progress Horizontal Priority 'Health for All' } \\
\text { Interinstitutional Operations Plan (2014; } \\
\text { primary) }{ }^{\star * 67}\end{array}$ & 2014-2020 & No & $\begin{array}{l}\text { Prevention } \\
\text { +management }\end{array}$ & $\begin{array}{l}\text { To coordinate measures to enhance public health } \\
\text { outcomes and implement the principle of health in all } \\
\text { policies to achieve closer interagency cooperation on } \\
\text { public health issues. }\end{array}$ \\
\hline & $\begin{array}{l}\text { The National Public Healthcare } \\
\text { Development Programme for 2016-2023 } \\
\left(2015 ; \text { primary) }{ }^{* 68}\right.\end{array}$ & 2016-2023 & No & $\begin{array}{l}\text { Prevention } \\
\text { +management }\end{array}$ & $\begin{array}{l}\text { To set goals, tasks, assessment criteria and anticipated } \\
\text { values of national public healthcare strategies and } \\
\text { to ensure implementation of public healthcare goals } \\
\text { and tasks set in the Lithuanian Health Programme for } \\
2014-2025 \text {. }\end{array}$ \\
\hline $\begin{array}{l}\text { Mexico } \\
\text { (upper } \\
\text { middle) }\end{array}$ & $\begin{array}{l}\text { National Strategy for the Prevention } \\
\text { and Control of Overweight, Obesity and } \\
\text { Diabetes (2013; primary })^{69}\end{array}$ & n.s. & Yes & $\begin{array}{l}\text { Prevention } \\
\text { +management }\end{array}$ & $\begin{array}{l}\text { To improve the well-being of the population and } \\
\text { contribute to the sustainability of national development } \\
\text { by decreasing the prevalence of overweight and } \\
\text { obesity among Mexicans, in order to impact the } \\
\text { epidemic of non-communicable diseases, particularly } \\
\text { type } 2 \text { diabetes, through public health interventions, } \\
\text { a comprehensive model of medical attention and } \\
\text { intersectoral political action. }\end{array}$ \\
\hline $\begin{array}{l}\text { The } \\
\text { Netherlands } \\
\text { (high) }\end{array}$ & All about health $(2013 \text {; primary })^{\star 70}$ & 2014-2016 & No & Prevention & $\begin{array}{l}\text { To promote individual health and prevent chronic } \\
\text { illness by means of an integrated approach within the } \\
\text { settings in which people live, work and learn; give } \\
\text { prevention a prominent place within healthcare; and } \\
\text { maintain the quality of health protection, responding } \\
\text { promptly to any new threats. }\end{array}$ \\
\hline $\begin{array}{l}\text { Norway } \\
\text { (high) }\end{array}$ & $\begin{array}{l}\text { NCD-Strategy 2013-2017. For the } \\
\text { prevention, diagnosis, treatment and } \\
\text { rehabilitation of four non-communicable } \\
\text { diseases: cardiovascular disease, diabetes, } \\
\text { COPD and cancer (2013; primary) }{ }^{* 1}\end{array}$ & 2013-2017 & Yes & $\begin{array}{l}\text { Prevention } \\
\text { +management }\end{array}$ & $\begin{array}{l}\text { To reduce premature death from cardiovascular } \\
\text { disease, diabetes, chronic lung disease and cancer by } \\
25 \% \text { by } 2025 \text {. }\end{array}$ \\
\hline $\begin{array}{l}\text { Poland } \\
\text { (high) }\end{array}$ & $\begin{array}{l}\text { The National Health Programme for the } \\
\text { years 2016-2020, Council of Ministers' } \\
\text { Decree (2016; primary) }{ }^{* * 72}\end{array}$ & 2016-2020 & Yes & $\begin{array}{l}\text { Prevention } \\
\text { +management }\end{array}$ & $\begin{array}{l}\text { To extend healthy life, improve health and related } \\
\text { quality of life of the population, and reduce social } \\
\text { inequalities in health. }\end{array}$ \\
\hline $\begin{array}{l}\text { Portugal } \\
\text { (high) }\end{array}$ & $\begin{array}{l}\text { National Health Plan } 2020 \text { Review and } \\
\text { Outreach (2015; primary) }{ }^{\star * 38}\end{array}$ & 2015-2020 & Yes & $\begin{array}{l}\text { Prevention } \\
\text { +management }\end{array}$ & $\begin{array}{l}\text { To maximise the health gains by integrating sustained } \\
\text { efforts in all sectors of society, and the use of } \\
\text { strategies based on citizenship, equity and access in } \\
\text { quality and in healthy policies. }\end{array}$ \\
\hline $\begin{array}{l}\text { Slovakia } \\
\text { (high) }\end{array}$ & $\begin{array}{l}\text { Updated National Health Promotion } \\
\text { Programme in the Slovak Republic (2014; } \\
\text { primary) })^{* * 73}\end{array}$ & 2014-2030 & No & Prevention & $\begin{array}{l}\text { To achieve a long-term improvement in the health } \\
\text { of the Slovak population, extending life expectancy } \\
\text { and quality of life, eliminating the incidence of health } \\
\text { disorders that reduce quality of life and threaten } \\
\text { premature human death. The policy is primarily } \\
\text { aimed at influencing the determinants of health, } \\
\text { reducing population-based risk factors and increasing } \\
\text { involvement of various sectors of society. }\end{array}$ \\
\hline $\begin{array}{l}\text { Slovenia } \\
\text { (high) }\end{array}$ & $\begin{array}{l}\text { Resolution on the National Healthcare Plan } \\
2016-2025 \text { (2016; primary) })^{* 74}\end{array}$ & 2016-2025 & No & $\begin{array}{l}\text { Prevention } \\
\text { +management }\end{array}$ & $\begin{array}{l}\text { To promote health and prevent diseases; optimise } \\
\text { healthcare; enhance the performance of the healthcare } \\
\text { system; and achieve equity, solidarity and sustainability } \\
\text { in financing of healthcare. }\end{array}$ \\
\hline $\begin{array}{l}\text { Spain } \\
\text { (high) }\end{array}$ & $\begin{array}{l}\text { Strategy for Addressing Chronicity in the } \\
\text { National Health System (2012; primary) }\end{array}$ & n.s. & No & $\begin{array}{l}\text { Prevention } \\
\text { +management }\end{array}$ & $\begin{array}{l}\text { To decrease the prevalence of health conditions } \\
\text { and chronic limitations of activity, reduce premature } \\
\text { mortality of people who already have any of these } \\
\text { conditions, prevent deterioration of functional capacity } \\
\text { and complications associated with each process, } \\
\text { and improve the quality of life of people and their } \\
\text { caregivers. }\end{array}$ \\
\hline
\end{tabular}

Continued 
Table 1 Continued

\begin{tabular}{|c|c|c|c|c|c|}
\hline $\begin{array}{l}\text { Nation } \\
\text { (income } \\
\text { bandt) }\end{array}$ & $\begin{array}{l}\text { Policy title (year of publication; } \\
\text { classification } \ddagger \text { ) }\end{array}$ & Time span & $\begin{array}{l}\text { Explicit } \\
\text { alignment } \\
\text { with the } \\
\text { WHO Action } \\
\text { Plan§ (yes/ } \\
\text { no) }\end{array}$ & $\begin{array}{l}\text { Focus (NCD } \\
\text { prevention; } \\
\text { NCD } \\
\text { management; } \\
\text { both) }\end{array}$ & Purpose, aim or vision \\
\hline \multirow[t]{2}{*}{$\begin{array}{l}\text { Sweden } \\
\text { (high) }\end{array}$} & $\begin{array}{l}\text { A person-centred public health policy (2012; } \\
\text { primary })^{76}\end{array}$ & n.s. & No & Prevention & To present a person-centred public health policy. \\
\hline & $\begin{array}{l}\text { A cohesive strategy for alcohol, narcotic } \\
\text { drugs, doping and tobacco (ANDT) policy } \\
(2011 ; \text { primary) })^{\star 77}\end{array}$ & 2011-2025 & No & $\begin{array}{l}\text { Prevention } \\
\text { +management }\end{array}$ & $\begin{array}{l}\text { A society free from illegal drugs and doping, with } \\
\text { reduced alcohol-related medical and social harm, and } \\
\text { reduced tobacco use. }\end{array}$ \\
\hline \multirow[t]{2}{*}{$\begin{array}{l}\text { Switzerland } \\
\text { (high) }\end{array}$} & $\begin{array}{l}\text { Action plan for the National Strategy on the } \\
\text { Prevention of Non-Communicable Diseases } \\
\text { (NCD-Strategy) 2017-2024 (2016; primary) }^{78}\end{array}$ & 2017-2024 & Yes & $\begin{array}{l}\text { Prevention } \\
\text { +management }\end{array}$ & $\begin{array}{l}\text { To improve the coordination between actors and } \\
\text { agencies and to increase the efficiency in prevention } \\
\text { and health promotion. }\end{array}$ \\
\hline & $\begin{array}{l}\text { National strategy for the prevention of non- } \\
\text { communicable diseases (NCD-Strategy) } \\
\text { 2017-2024 (2016; primary) }\end{array}$ & $2017-2024$ & Yes & $\begin{array}{l}\text { Prevention } \\
\text { +management }\end{array}$ & $\begin{array}{l}\text { More people stay healthy or have, despite chronic } \\
\text { illness, a high quality of life. Less people fall ill with } \\
\text { avoidable, non-communicable diseases or die } \\
\text { prematurely. Independent of their socioeconomic } \\
\text { status, people are enabled to have a healthy lifestyle in } \\
\text { a conducive healthy environment. }\end{array}$ \\
\hline $\begin{array}{l}\text { Turkey } \\
\text { (upper } \\
\text { middle) }\end{array}$ & $\begin{array}{l}\text { Multisectoral Action Plan of Turkey for Non- } \\
\text { communicable Diseases 2017-2025 (2017; } \\
\text { primary) })^{* 39}\end{array}$ & $2017-2025$ & Yes & $\begin{array}{l}\text { Prevention } \\
\text { +management }\end{array}$ & $\begin{array}{l}\text { To raise the health and well-being of the Turkish } \\
\text { population through reducing preventable deaths and } \\
\text { the disability burden attributable to NCDs and thus } \\
\text { enabling citizens to maintain the highest attainable } \\
\text { health status at all ages. }\end{array}$ \\
\hline $\begin{array}{l}\text { United } \\
\text { Kingdom } \\
\text { (high) }\end{array}$ & $\begin{array}{l}\text { Living Well for Longer: A call for action to } \\
\text { reduce avoidable premature mortality (2013; } \\
\text { primary }{ }^{\star 80}\end{array}$ & n.s. & No & $\begin{array}{l}\text { Prevention } \\
\text { +management }\end{array}$ & $\begin{array}{l}\text { To challenge and inspire the health and care system, in } \\
\text { its widest sense, to take action to reduce the numbers } \\
\text { of people dying prematurely, defined as premature } \\
\text { deaths due to cancer, heart disease, stroke, respiratory } \\
\text { disease and liver disease under the age of } 75 \text { years. }\end{array}$ \\
\hline $\begin{array}{l}\text { United } \\
\text { States of } \\
\text { America } \\
\text { (high) }\end{array}$ & $\begin{array}{l}\text { National Prevention Council Action Plan: } \\
\text { Implementing the National Prevention } \\
\text { Strategy }\left(2012 ; \text { primary) }{ }^{\star 81}\right.\end{array}$ & $\begin{array}{l}\text { n.s. The } \\
\text { development } \\
\text { of a } \\
\text { pragmatic }\end{array}$ & No & Prevention & $\begin{array}{l}\text { To identify National Prevention Council shared } \\
\text { departmental commitments and unique department } \\
\text { actions to further each of the strategic directions and } \\
\text { priorities of the National Prevention Strategy. }\end{array}$ \\
\hline
\end{tabular}

*Source document published in English.

** Source document translated to English.

†Classification: documents classified as primary or secondary. Primary documents are full or stand-alone national or jurisdictional policy or strategy documents. Primary documents may be brief, but should be interpretable as a stand-alone document. Secondary documents accompany primary documents (eg, infographics, summary pages, excerpts from primary documents) and do not represent the full policy or document.

‡Refers to the WHO Global Action Plan for the Prevention and Control of Non-communicable Diseases 2013-2020. ${ }^{21}$

COPD, chronic obstructive pulmonary disease;NCD, non-communicable disease; n.s., not stated.

ability. The context in which musculoskeletal health was mentioned included:

- Within prevention and management strategies for NCDs ( $n=12$ policies);

- A leading cause of disability in the country $(n=8$ policies);

- A determinant of healthy ageing ( $\mathrm{n}=4$ policies);

- A priority condition for care pathways ( $\mathrm{n}=2$ policies);

- Arthritis as a priority condition ( $\mathrm{n}=3$ policies);

- Conditions amenable to lifestyle/behaviour change ( $\mathrm{n}=3$ policies);

- An indicator for population health monitoring $(\mathrm{n}=1$ policy).

\section{Strategies outlined within and across policies, including relevance to musculoskeletal health, pain and mobility}

General strategies to address the stated policy aims were outlined in $42(95.5 \%)$ policies. From these, all strategies were relevant to prevention/management of musculoskeletal health, pain and mobility/functional ability in $12(28.6 \%)$ policies, some were relevant in $27(64.3 \%)$ policies and none were relevant in $3(7.1 \%)$ policies. Thirty first-order codes were derived to summarise these general strategies. An additional 12 first-order codes were derived to summarise strategies specific to the prevention or management of musculoskeletal conditions, pain or mobility/functional ability. This resulted in a net 42 first-order codes, and these were subsequently aggregated into three overarching themes with supporting subthemes (figure 2; table 3). Twenty-eight $(93.3 \%)$ of the 30 first-order codes in table 3 describing general policy strategies were relevant to the prevention/management of musculoskeletal health conditions, persistent pain or loss of functional ability/mobility (range: $2.1 \%-71.4 \%$ of policies), with the exception of 1.2.1 and 3.1.1. The frequency of policies with strategies specific to musculoskeletal health (ie, general strategies linked to musculoskeletal health based on the initial 30 first-order codes, or strategies cited in policies as explicitly related to musculoskeletal health based on the additional 12 first-order codes), is also included in table 3; range: $2.6 \%-55.3 \%$ of policies. A narrative meta-synthesis of the themes aligned to general and specific strategies is provided below. 


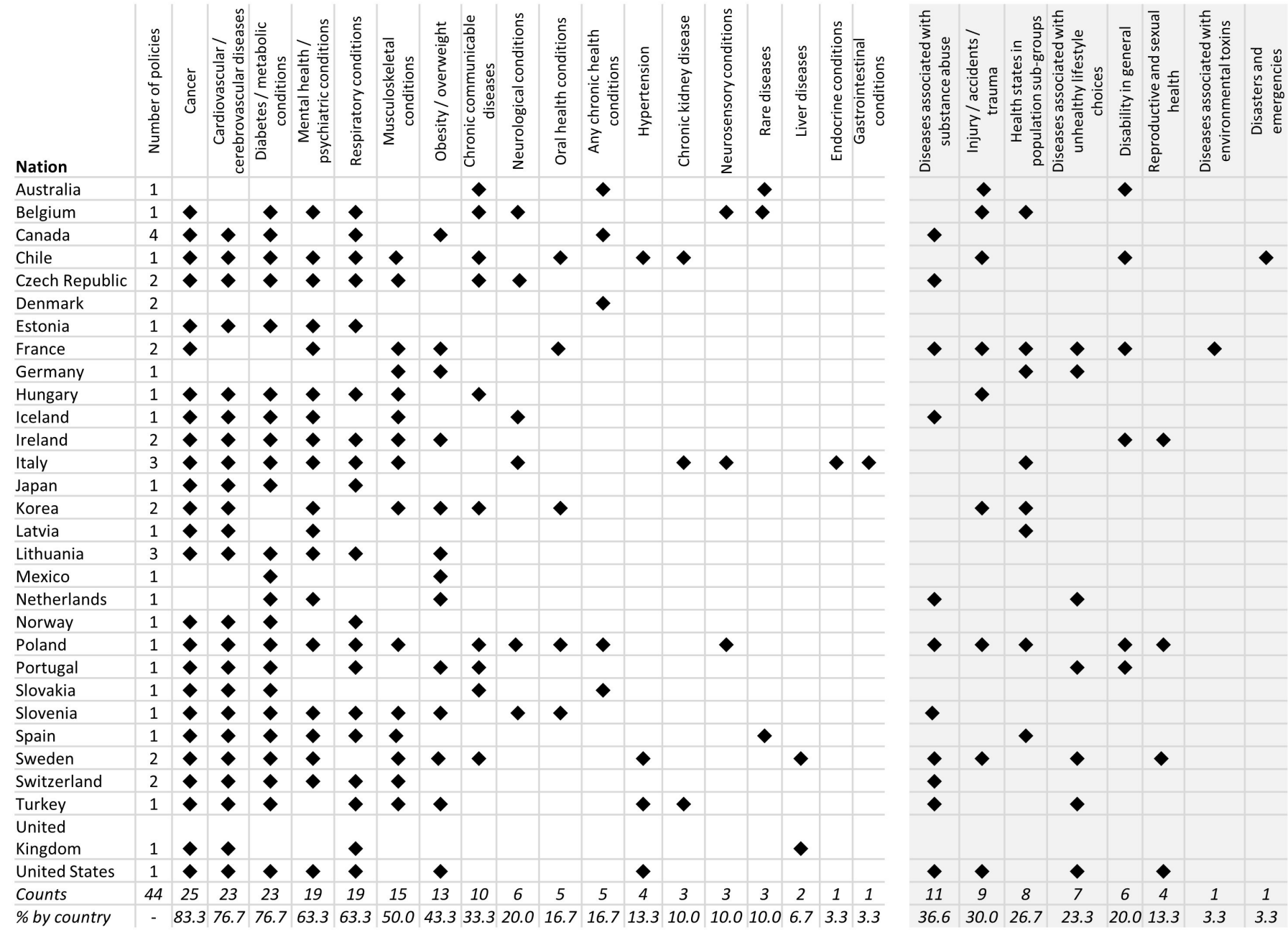

Figure 1 Frequency map of diseases/health conditions (left panel) and health states (right panel) explicitly cited as within the scope or coverage of the included policies by nation. Musculoskeletal conditions encompass any condition of the musculoskeletal system or persistent non-cancer pain. Neurological conditions include any neurological or neurodegenerative condition.

General principles for people-centred NCD prevention and management

Policies strongly identified that NCD prevention and management should be based on a continuum of care across the life course. Further, NCD prevention and management should be underpinned by a people-centred (biopsychosocial) approach to planning and delivery. In addition to optimising health, this should consider social and financial consequences and the risks associated with NCDs. Efforts to prevent and manage NCDs should consider healthy behaviours (nutrition, physical activity, safe use of substances) with a strong focus on obesity prevention and management; facilitating a healthy environment (including food safety, air/noise/chemical pollution, climate change); and supporting an active lifestyle. In particular, a focus on increasing population-level physical activity and reducing sedentary exposure across all ages and environments (school, work, home) through multifaceted programmes should be encouraged, monitored and measured. Promoting healthy behaviours and reducing risks for NCDs should also incorporate public health education tailored to target groups with the aim of improving health literacy, supporting positive health beliefs and encouraging effective self-management behaviours. Policies and programmes that target reducing the negative effects of alcohol, narcotics, doping substances and tobacco may also be helpful in reducing harm to people's musculoskeletal systems.

Person-centred NCD care that includes policy, service design and delivery should be developed and implemented through effective, cross-sector partnerships that include people and their families (including vulnerable groups), government, civil society, health services and industry.

Research that is accessible to decision makers, that addresses societal need in NCD prevention/ management, that considers emerging technologies/ technology innovations, that examines the value of complementary and alternative medicines, and is policy-relevant, was also cited as an important strategy in some policies. 


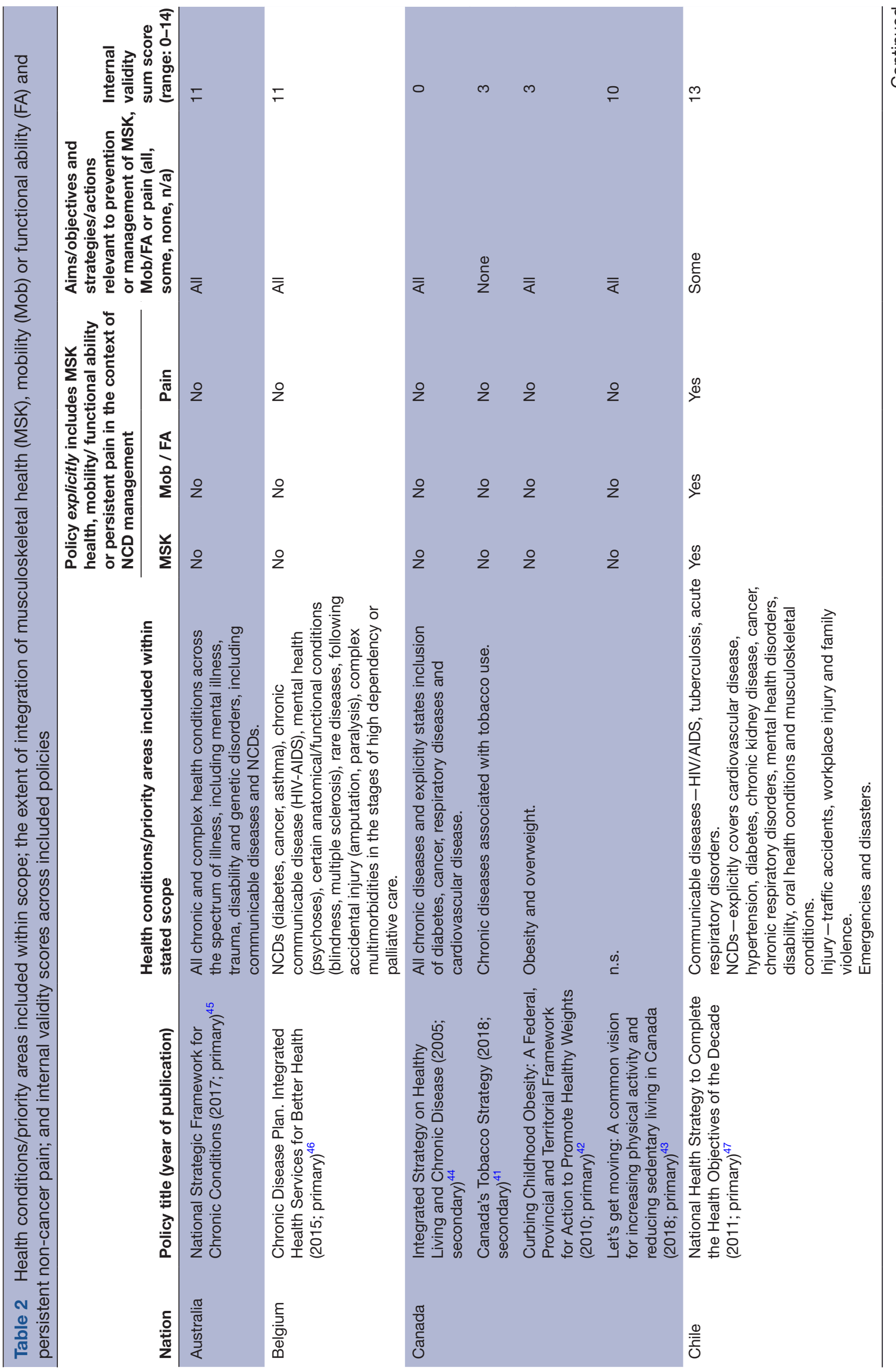




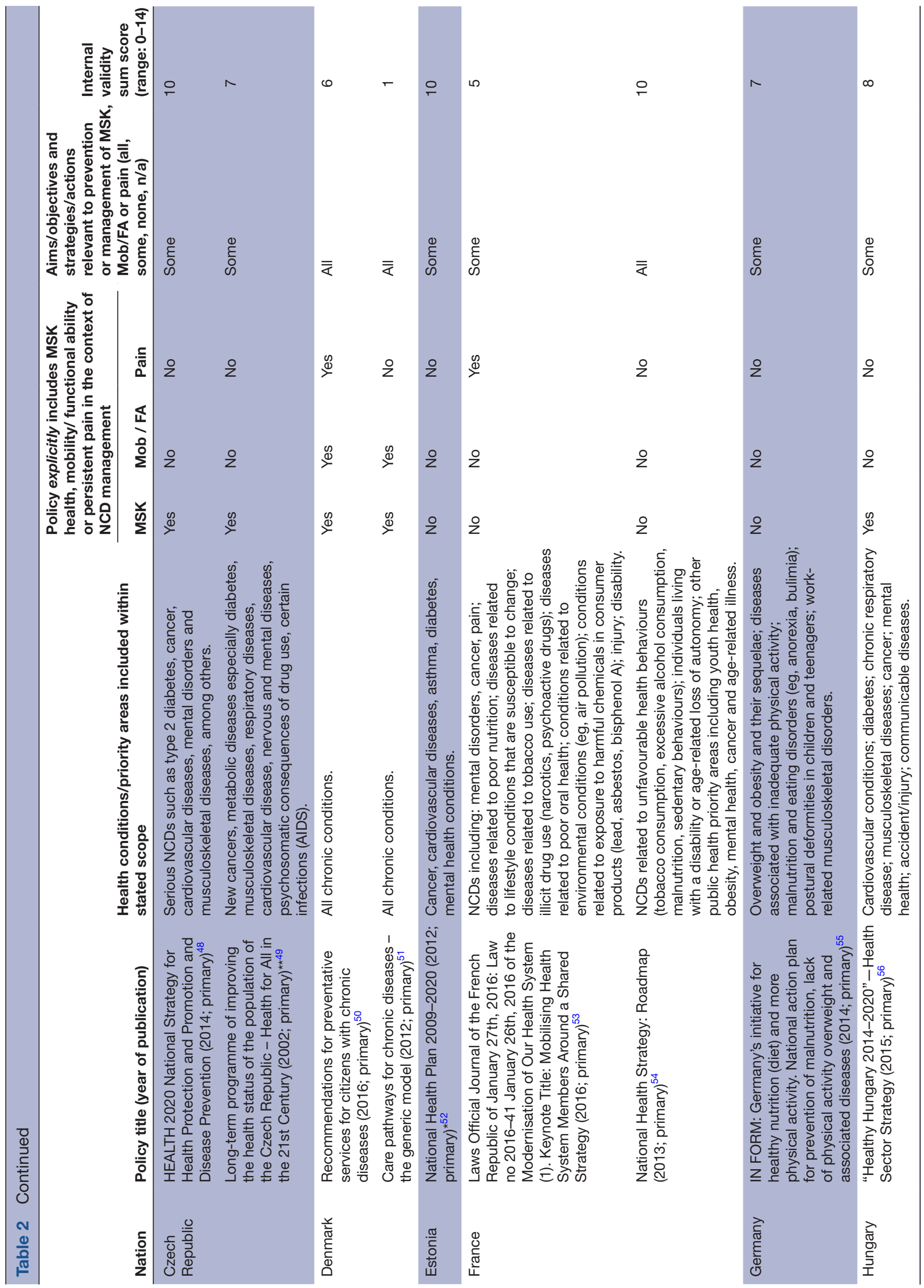




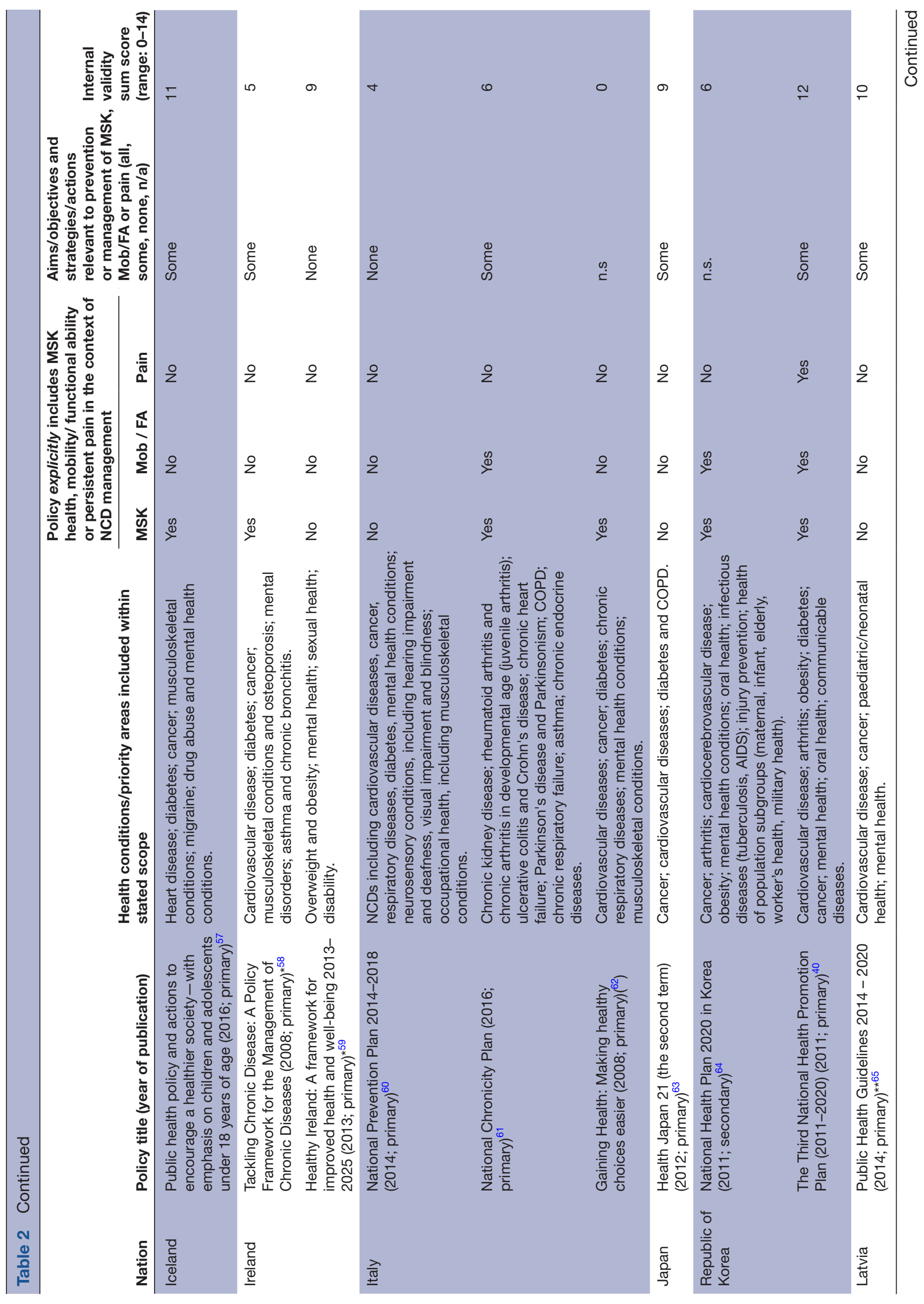

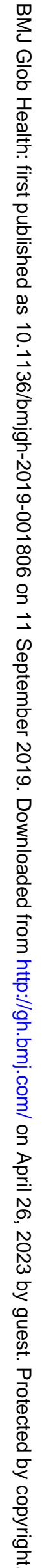




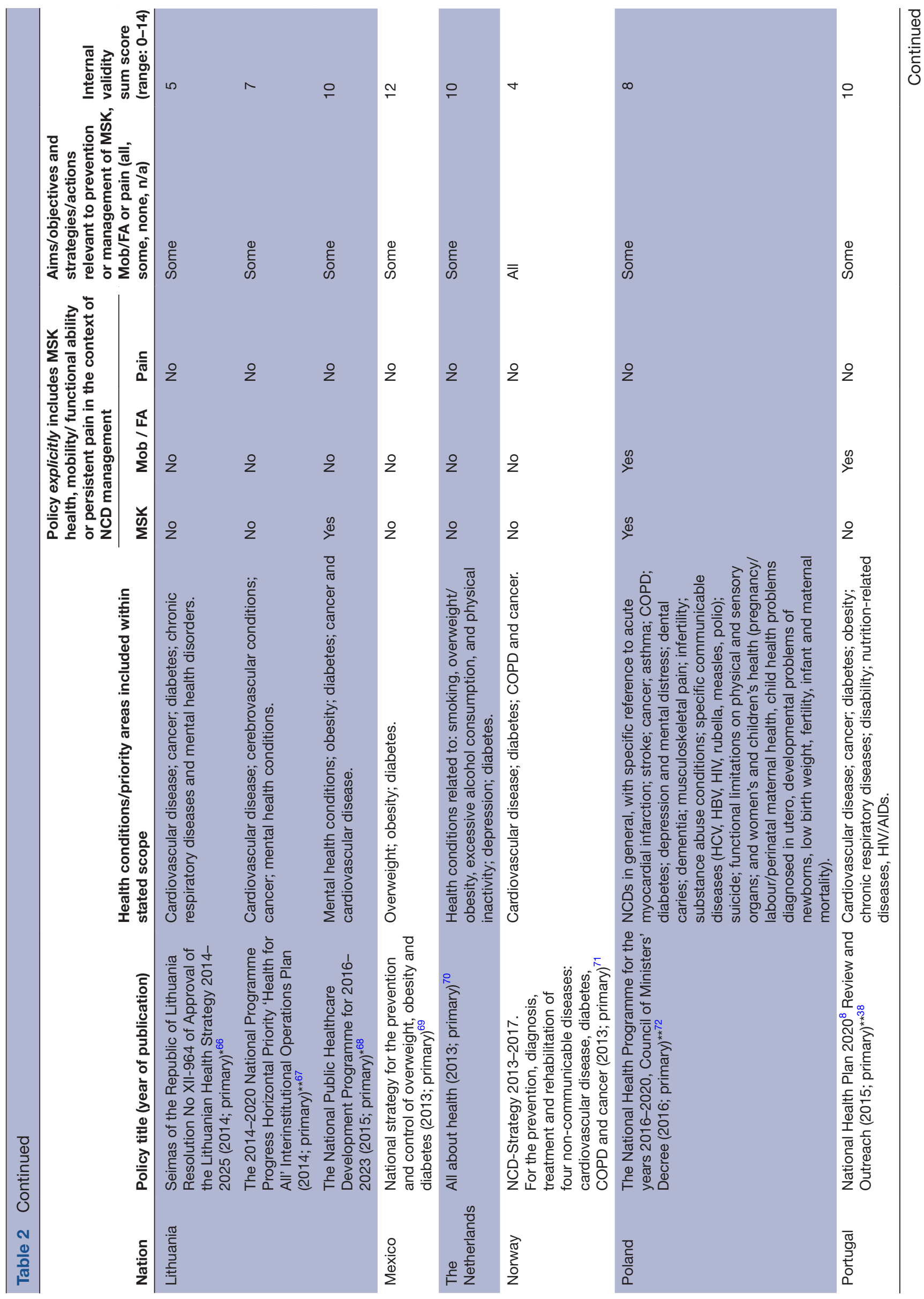




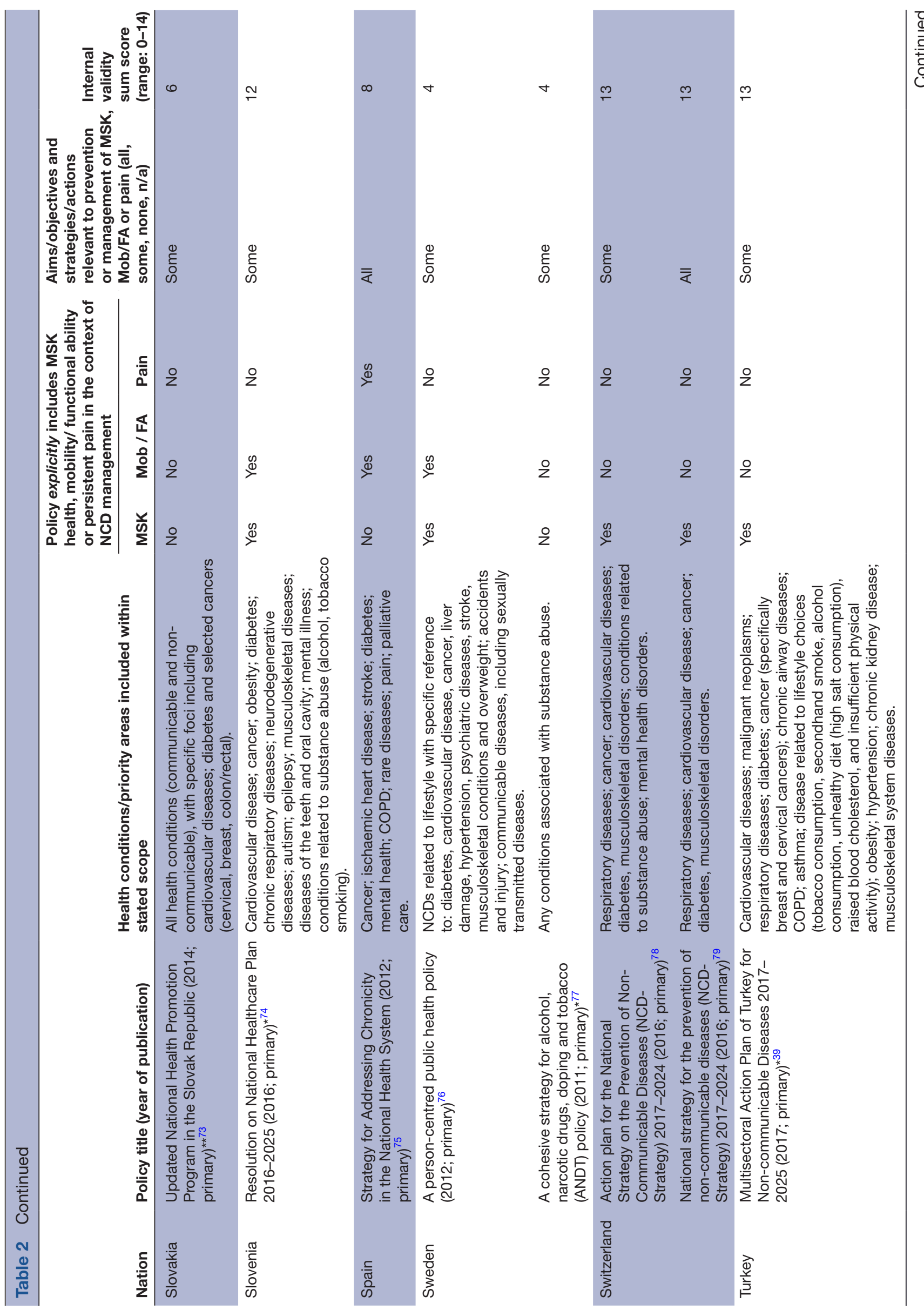




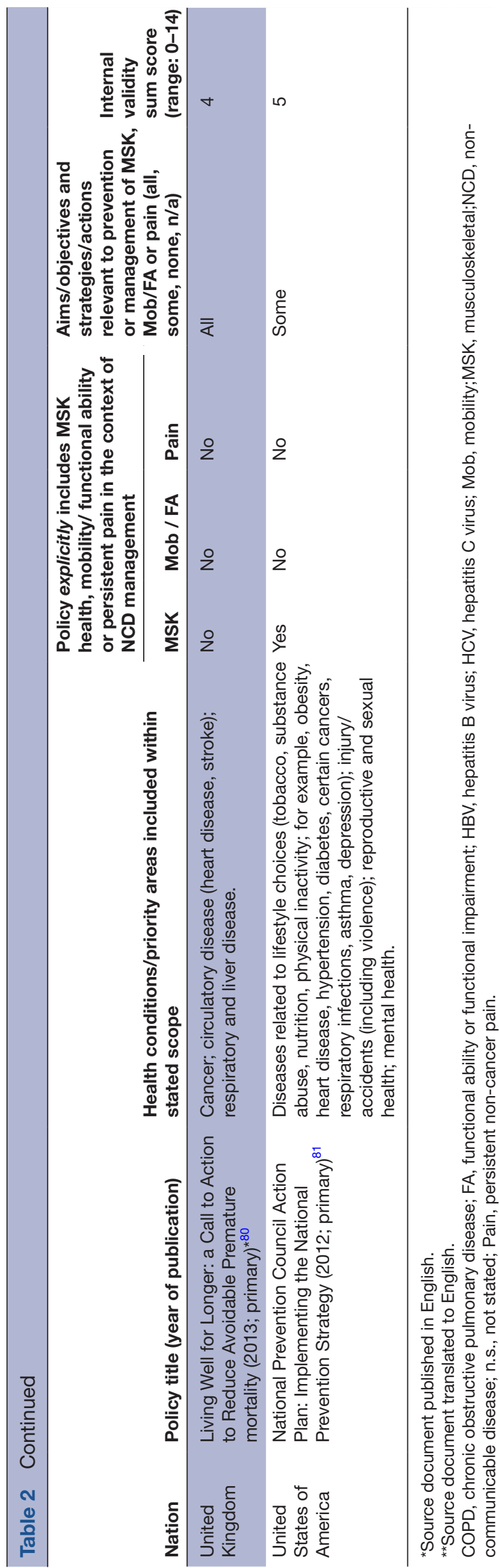

Service delivery

Interventions/programmes/services for NCD prevention/management should be effective based on health and cost outcomes, should be safe, and be acceptable to consumers. In the context of prevention, timely interventions to identify and manage risk factors, to enable early diagnosis (eg, health checks, screening, education campaigns), and to enable risk classification/stratification, was identified as important. For musculoskeletal health specifically, some policies rationalised the need to include disability assessments as part of national health checks while others cited the need for strategies to prevent injuries across various settings (work, school, recreational).

In the context of disease management, evidence from policies supported that NCDs may be addressed through disease-specific and technology-enabled models of care. Such models must address a specific population/clinical group (such as the Danish care pathway for musculoskeletal conditions); be informed by clinical guidelines/ evidence and by criteria that support effective clinical decision making (eg, improved diagnostics) and adopt appropriate stepped care; and identify implementation strategies and mechanisms for monitoring effectiveness, safety and quality improvement. Specific to musculoskeletal health, some policies identified the need to support specific strategies for obesity prevention/reduction, to improve mental healthcare and for targeting arthritis as a specific priority condition.

Policies identified that improved NCD management may be achieved through services that are accessible (ie, geographically accessible, accessible thorugh appropriate infrastructure, and supported by technology eg telehealth and information exchange to improve access) irrespective of age, gender, residence and socioeconomic status; and that are culturally acceptable. Access to essential medicines and laboratory medicine facilities were considered critical. Leveraging digital technologies to mitigate care disparities imposed by geographical and socioeconomic barriers and to facilitate access to highvalue NCD care for vulnerable groups/populations, was supported.

Where possible, evidence suggested that health services should be delivered in community settings by multidisciplinary care teams. For musculoskeletal health specifically, rehabilitation providers within multidisciplinary teams and community-based rehabilitation services were seen as important, together with comprehensive care plans that support return to work and/or social participation. To ensure holistic care, policies indicated that service delivery should be integrated between services, settings and regions. Capacity building in the workforce was highlighted as a critical enabler to supporting the delivery of the right NCD care (eg, development of core competencies that include ageing, mental health, obesity management, physical activity), with a particular focus on primary care providers. 
Theme 1: General principles for people-centred NCD prevention and management

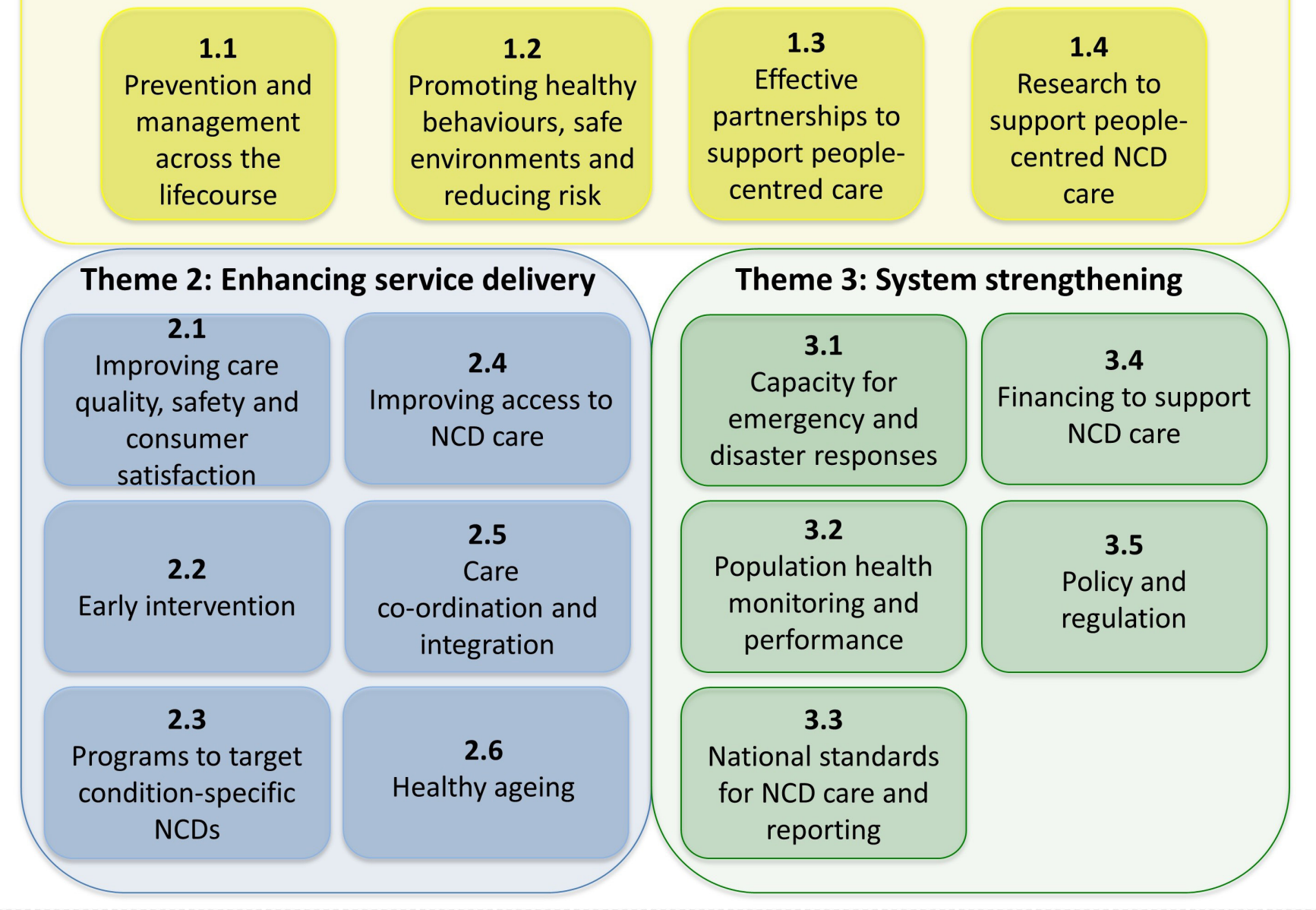

Figure 2 Schematic of the themes and subthemes describing the strategies outlined in the included policies for integrated management of non-communicable diseases (NCDs). The themes align with the WHO Framework on Integrated PeopleCentred Health Services (IPCHS). ${ }^{85}$. Theme 1 aligns with IPCHS strategy 1 ('engaging and empowering people and communities'); theme 2 aligns with IPCHS strategies 3 and 4 ('reorienting the model of care' and 'coordinating services within and across sectors', respectively); theme 3 aligns with IPCHS strategy 5 ('creating an enabling environment').

In the context of supporting older people living with NCDs, policies recommended the implementation of specific strategies and indicators to support healthy ageing, including: health promotion, health checks, interventions to address functional impairments, development of a model of care for older people that includes geriatric care and support for long-term care systems.

\section{System strengthening}

To inform NCD prevention/management planning and system-level responses, there is a need for population health monitoring. Relevant system performance targets should include NCD risk factor reduction, prevention of premature mortality, morbidity reduction, disease incidence reduction, reduction in health economic burden associated with NCD care, and health inequality and care disparity reductions. To support health systems, there is a need to establish national care/quality standards and standardise reporting practices for NCDs. Findings suggested a need to develop guidelines or quality care standards that are relevant for people living with musculoskeletal health impairments, such as rehabilitation and disability guidelines. At a broader level, building capacity in the system to respond to health disasters and epidemics was identified as important.

Financing for NCD care was considered essential to address long-term health spending, to ensure appropriate resourcing of policy/programme implementation initiatives, to ensure there are compulsory insurance schemes to act as a mechanism for financial sustainability (eg, universal health insurance), and to support funding of only interventions and technologies with proven effectiveness and safety, and finally, develop and implement financing models linked to performance and quality. In the context of positively influencing musculoskeletal health services, providing appropriate financing for rehabilitation services and for social and financial support packages for people living with disability, were identified 
Table 3 Summary of overarching themes, supported by subthemes and first-order codes to describe the scope and content of the strategies outlined in the included policies. Frequencies of general strategies and frequencies of specific strategies relevant to musculoskeletal (MSK) health, pain or mobility/functional ability, by policy, are included to provide a measure of prominence for first-order codes. Frequencies are colour coded for ease of interpretation (red $<25 \%$; amber $\geq 25 \%$ to $<50 \%$; green $\geq 50 \%$ ).

Frequency of policies with general strategies; $n$ (\%) with strategies relevant to MSK, pain or mobility/functional

Theme 1: General principles for people-centred NCD care

1.1 NCD prevention and management across the life course

1.2 Promoting healthy behaviours, safe environments and reducing risk

1.1.1 NCD prevention/management should be based on a care continuum across the life course from prevention (including maternal and child healthcare) through to rehabilitation and palliative care that is tailored to the individual's needs and that considers physical health, mental well-being and injury protection. A focus on vulnerable groups should be prioritised.

1.1.2 NCD prevention/management should include initiatives that address social and financial consequences of, or risk factors for, NCDs and that promote physical and social function

1.1.3 NCD management should adopt a people-centred model in service delivery.

1.2.1 NCD prevention/management should be based on promoting a healthy and safe environment to minimise risk factors for NCDs including food safety, exposure to chemicals, air and noise pollution, and climate change. This approach should extend to education and work environments.

1.2.2 NCD prevention/management should support the development and implementation of multifaceted interventions to increase the volume of physical activity (PA) and reduce sedentary behaviour at the population level targeting all ages (eg, population awareness campaigns; supportive environments and transport options; work and school-based PA; leadership in PA initiatives; upskilling teachers in PA) with indicators to monitor performance.

1.2.3 NCD prevention/management should be based on promoting healthy behaviours/ lifestyles to minimise risk factors for NCDs (primary and secondary prevention) with a strong focus on obesity management. Foci should include healthy lifestyle (nutrition focusing on a reduction of sugar, salt and saturated fats; PA; safe use of alcohol/ tobacco; minimising substance abuse especially in youth; mental health strategies; and oral hygiene). This approach should extend to education and work environments, with particular attention paid to supporting healthy lifestyle environments for children in schools.

1.2.4 NCD prevention/management should include public health education that is accessible and disseminated across various settings (eg, work, education/school, kindergarten) and is tailored to target groups, with the outcome being a change in health beliefs and empowering positive health behaviours (improved health literacy) and improved capacity for self-management. In some settings, mass media is recommended.

1.2.5 +NCD prevention/management should support the development and implementation of policies and/or programmes that target reducing the potentially negative effects of alcohol, narcotics, doping substances and tobacco (ANDT) on the MSK system, on the mental health system and that reduce the chances of injury to the MSK system.

1.3 Effective 1.3.1 NCD prevention/management efforts (inclusive of service delivery, service design partnerships to support and policy formulation) should be approached with effective partnerships across the people-centred care sector (eg, government, civil society, volunteers, health services, industry) and with consumers and their families, including indigenous communities.

1.4 Research to support peoplecentred NCD care

1.4.1 NCD prevention/management should support research that is accessible to decision makers, that addresses societal need in NCD prevention/management, that considers emerging technologies/technology innovations, that examines the value of complementary and alternative medicines, and is system-relevant.

\section{Theme 2: Service delivery}

2.1 Improving care quality, safety and consumer satisfaction

2.2 Early intervention
2.1.1 Deliver interventions or services that are effective and safe (high-value) and that improve care quality and consumer satisfaction.

2.1.2 Prevention initiatives (eg, programmes, policies) should be underpinned by quality criteria for NCD prevention, including evaluation of effectiveness.

2.2.1 NCD prevention should include timely interventions to identify and manage risk factors, enable early diagnosis (eg, health checks, screening, education campaigns) and enable risk classification/stratification.

2.2.2 †National health assessments or 'health checks' should include assessment of disability.

2.2.3 †Implement strategies and policy for injury prevention at work, for leisure and sport and that monitor injury prevalence. $16(38.1)^{\star}$

$13(31.0)^{\star}$

15 (35.7)

$14(33.3)^{*}$

$16(42.1)$
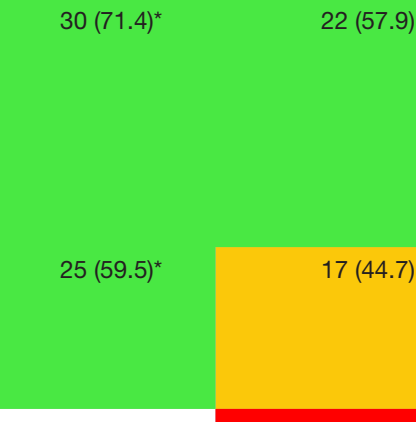

$21(50.0)^{\star}$

$11(28.9)$

$12(28.6)^{\star}$

$15(35.7)^{\star}$

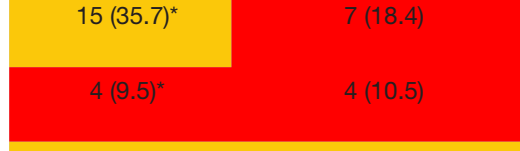

$20(47.6)^{\star}$

$14(36.8)$

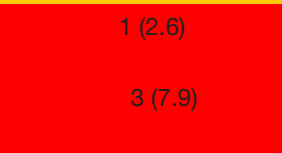

Continued 
Table 3 Continued

Subthemes

2.3 Programmes targeting conditionspecific NCDs
First-order codes describing strategies contained in policies

2.3.1 NCD management of major conditions should include programmes that are evaluated and supported by disease-specific clinical guidelines and established criteria for diagnosis and stratification. Mechanisms to update programmes based on new evidence should be included.

2.3.2 NCDs management should include disease-specific and technology-enabled models of care, that address a specific population or condition/disease group and contain evidence-based components of care, implementation strategies, and mechanisms for monitoring and quality improvement.

2.3.3 †NCD management should include support strategies for obesity reduction/ prevention strategies, in addition to general nutrition and PA strategies.

2.3.4 †Support delivery of mental healthcare through targeted health promotion, through accessible services (inclusive of mind-body therapies) and through provider training in mental healthcare.

2.3.5 †Support specific system and service strategies for arthritis (identification of disease, supporting adherence to pharmacological and non-pharmacological care, integrated management between health services and clinicians, development of models of service delivery and models of care).

2.4 Improving access 2.4.1 Support NCD management by harnessing digital technologies (eg, eHealth, to NCD care

2.5 Care coordination and integration

telehealth, electronic medical records) to enable information/service access and exchang for consumers and health professionals to support self-management, system navigation and care delivery.

2.4.2 Support accessible NCD care services (geographically accessible, appropriate infrastructure, ICT support) irrespective of age, gender, residence and socioeconomic status, and ensure that services are culturally acceptable.

2.4.3 NCD prevention and management needs to be supported by population access to essential medicines and essential laboratory medicine.

2.5.1 Create community-based, multidisciplinary healthcare teams responsive to local needs, supported by a referral network for providers.

2.5.2 Build and monitor capacity/competencies in the workforce (particularly in primary care) to deliver high-value NCD care, including a focus on ageing, mental health, obesity management, PA and competencies in technology use.

2.5.3 Support care coordination between the workforce and support coordination and integration between services, regions and existing programme (eg, with ICT infrastructure, referral networks)

2.5.4 †Ensure that health facilities have rehabilitation professionals working in multidisciplinary teams.

2.5.5 †Ensure that citizens who have NCDs have comprehensive health plans developed, inclusive of supports for return to work.

2.5.6 †Support the provision of community-based rehabilitation services, especially in areas where care disparities exist.

2.6 Supporting healthy 2.6.1 In the context of supporting older people living with NCDs, implement specific ageing strategies and indicators to support healthy ageing (health promotion; health checks; interventions to address functional impairments; develop models of care for older people that include geriatric care and long-term care systems).

Theme 3: System strengthening

\subsection{Capacity for} emergency response to disasters and epidemics

3.2 Population health monitoring and performance
3.1.1 Strengthen emergency response capacity to better manage disasters and epidemics.

3.2.1 To inform NCD prevention and management initiatives, population health monitoring/ surveillance is needed through electronic health information systems, that should include health and injury outcomes and the social determinants of health.

3.2.2 Performance targets for NCD management/prevention should be based on: reduction in risk factors for NCDs; prevention of premature mortality; minimising morbidity (reduce disability and increase healthy life years); reduction in disease incidence; reduction in cost associated with NCDs; reduction in care disparities and health inequalities due to financial or social factors in vulnerable groups (eg, indigenous groups, ethnic minorities); and empowerment of citizens to more actively manage their health/participate in their healthcare.

\section{Frequency \\ of policies \\ with general \\ strategies; $n(\%)$ \\ ability care; $n(\%)$}

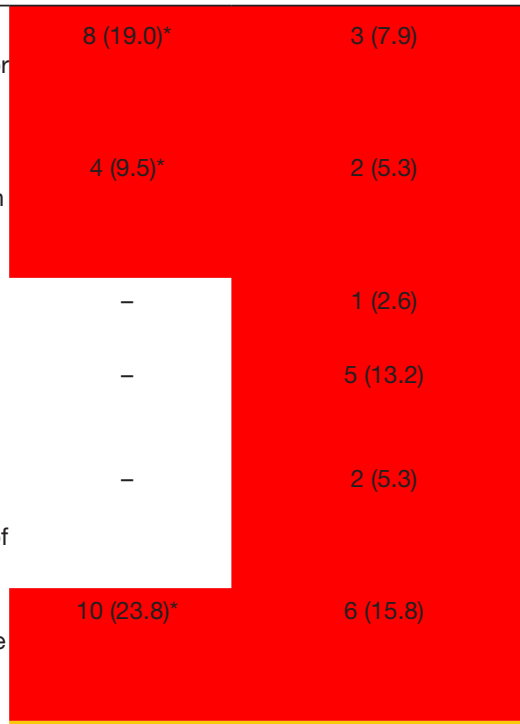

$17(40.5)^{\star}$

12 (31.6)

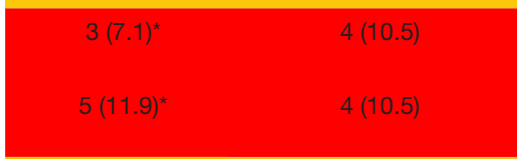

$17(40.5)^{\star} \quad 10(26.3)$

$20(47.6)$
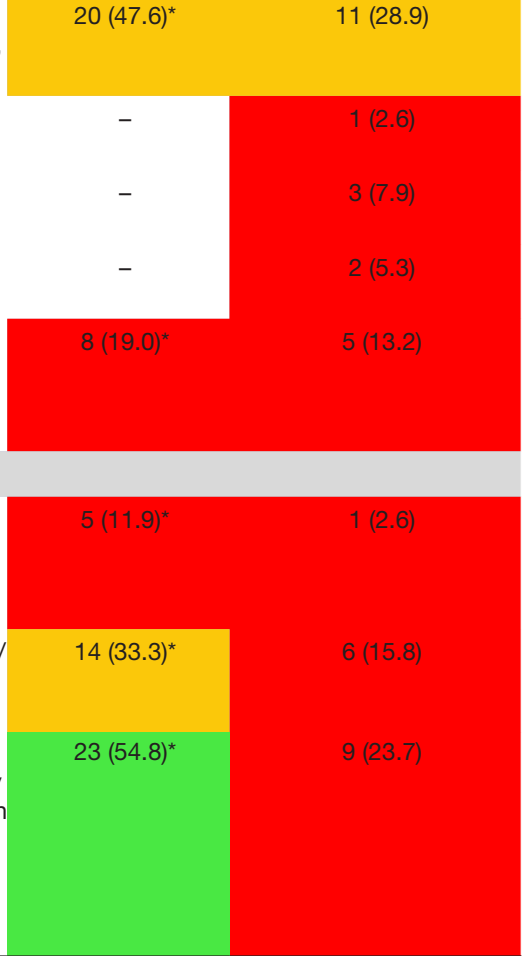

Continued 


\begin{tabular}{|c|c|c|c|}
\hline Subthemes & First-order codes describing strategies contained in policies & $\begin{array}{l}\text { Frequency } \\
\text { of policies } \\
\text { with general } \\
\text { strategies; } n(\%)\end{array}$ & $\begin{array}{l}\text { Frequency of policies } \\
\text { with strategies } \\
\text { relevant to MSK, pain } \\
\text { or mobility/functional } \\
\text { ability care; } \mathrm{n}(\%)\end{array}$ \\
\hline \multirow{2}{*}{$\begin{array}{l}3.3 \text { National care } \\
\text { standards and } \\
\text { reporting }\end{array}$} & $\begin{array}{l}\text { 3.3.1 Establish national care/quality standards and standardised reporting for NCDs, care } \\
\text { delivery and health outcomes to enable monitoring of care quality. }\end{array}$ & $8(19.0)^{\star}$ & $6(15.8)$ \\
\hline & $\begin{array}{l}\text { 3.3.2 †Develop care guidelines/quality standards relevant to the care of people with MSK } \\
\text { conditions (eg, rehabilitation guidelines; disability guidelines; community health promotion } \\
\text { guidelines that include PA, nutrition, injury prevention and mental health). }\end{array}$ & - & $1(2.6)$ \\
\hline \multirow[t]{3}{*}{$\begin{array}{l}\text { 3.4 Financing to } \\
\text { support NCD care }\end{array}$} & $\begin{array}{l}\text { 3.4.1 Financing for NCD care needs to consider long-term health spending, resources } \\
\text { to support implementation of policy/programmes, compulsory insurance, funding only } \\
\text { interventions and technologies with proven effectiveness, universal health insurance, and } \\
\text { payments linked to performance and quality. }\end{array}$ & $11(26.2)^{\star}$ & $7(18.4)$ \\
\hline & $\begin{array}{l}\text { 3.4.2 †Appropriately finance rehabilitation services to ensure appropriate quality care can } \\
\text { be delivered sustainably. }\end{array}$ & - & $1(2.6)$ \\
\hline & $\begin{array}{l}\text { 3.4.3 †Provide social and financial support packages for people living with disability and/ } \\
\text { or their carers. }\end{array}$ & - & $1(2.6)$ \\
\hline \multirow[t]{4}{*}{$\begin{array}{l}3.5 \text { Policy and } \\
\text { regulation }\end{array}$} & $\begin{array}{l}\text { 3.5.1 Ensure health, especially NCD prevention/management, is considered in all public } \\
\text { policy and interministerial activity (eg, social policy, ageing policy, employment policy), } \\
\text { including the evaluation of policies in terms of health impact. }\end{array}$ & $12(28.6)^{*}$ & $6(15.8)$ \\
\hline & 3.5.2 NCD prevention and management should be nationally prioritised agenda items. & $1(2.4)^{*}$ & $0(0)$ \\
\hline & $\begin{array}{l}\text { 3.5.3 NCD prevention and management requires strengthening of health governance } \\
\text { through the formulation of appropriate health and social policies. These should be } \\
\text { evidence-based, enable monitoring of outcomes that are aligned to international targets, } \\
\text { address the needs of people with disability and support citizens to actively and positively } \\
\text { manage their health. }\end{array}$ & $9(21.4)^{\star}$ & $5(13.2)$ \\
\hline & $\begin{array}{l}\text { 3.5.4 Develop and implement financial and marketing regulation and/or policy measures } \\
\text { to support citizens make healthy choices and limit unhelpful commercial influences on } \\
\text { health behaviours and outcomes (eg, nutritional information for food, making healthy food } \\
\text { affordable, regulation of advertising unhealthy foods, regulation of sales of illicit drugs via } \\
\text { social media, tobacco control). }\end{array}$ & $14(33.3)^{\star}$ & $4(10.5)$ \\
\hline
\end{tabular}

*Strategies relevant to the prevention/management of musculoskeletal health conditions, persistent pain or loss of functional ability/mobility.

†Additional codes added where strategies were specifically related to persistent pain or mobility/functional ability care.

ICT, information and communication technology; MSK, musculoskeletal; NCD, non-communicable disease; PA, physical activity.

as important factors for the prevention and management of musculoskeletal health, pain and mobility.

NCD prevention and management was considered as needing to be nationally prioritised and actioned through a whole-of-government approach. Health and social care policy was identified as necessary for NCD care and public health and policies indicated that this should be evidence-informed for effective prevention and management initiatives. Further, policy should explicitly allow for capture of outcomes that align with international targets. Regulation (eg, through policy and financial levers) also emerged as a key area that should be used to enable healthy lifestyle choices and support healthy behaviours; for example, disincentivising unhealthy foods, tobacco, substance use and unhelpful advertising.

\section{Implementation and internal validity}

Information to support implementation was provided in $38(86.4 \%)$ polices from $29(96.7 \%)$ countries. Across specific domains of implementation, priorities for implementation were described in $19(50.0 \%)$ policies, timelines or phasing of implementation activity in $23(60.5 \%)$ policies, financing arrangements to support implementation in $26(68.4 \%)$ policies, and identification of agencies responsible for implementation actions in 37 (97.4\%) policies (online supplementary file 4 provides these details by policy).

Internal validity sum scores ranged from 0 to 13 across policies, with a mean score of 7.6 (95\% CI 6.5 to 8.7$)$.

\section{DISCUSSION}

\section{Main findings}

To our knowledge, this is the first analytical review of contemporary health policies for the integrated management of NCDs among OECD Member States. This analysis provides an important snapshot of trends in aims and strategies for integrated management of NCDs among high-income nations, and for the first time, examines the extent of integration of musculoskeletal health as a leading cause of morbidity in most nations. Our findings are important for characterising and understanding the evidence on emergent priorities and strategies as outlined in contemporary health policies for NCDs, particularly in the context of the prevention/management of musculoskeletal health. We identified a broad range of internal validity scores among the included policies, suggesting diverse criteria for policy development across nations. From a broader NCD prevention and management perspective, our findings related to the aims and strategies outlined in the included policies 
align with many of the targets and indictors for the WHO NCD monitoring framework (eg, https://www.who. $\mathrm{int} / \mathrm{nmh} /$ global_monitoring_framework/en/), with a strong focus on mortality reduction, consistent with the target for SDG 3.4. Our meta-synthesis of aims and strategies provides evidence that aligns with a system-strengthening approach for NCDs, covering the important system building blocks of service delivery, health workforce, information and information systems, medical products and essential medicines, financing, and leadership and governance. ${ }^{82}$ The majority of countries $(63 \%-83 \%)$ had policies that focused on cancer, cardiovascular disease, diabetes and respiratory conditions. This is unsurprising given that these conditions are the foci of the WHO NCD monitoring framework, are most strongly associated with mortality, and are therefore more strongly linked to SDG target 3.4. Relative to other NCDs, musculoskeletal health did not feature as prominently.

\section{Integrated approaches to NCD prevention/management}

An integrated approach to NCD care is recognised as essential for effective system strengthening, ${ }^{278384}$ particularly in the context of an ageing population, an increasing prevalence of multimorbidity ${ }^{18}$ and in recognition of the limitations in LMICs to address multiple health states in parallel. ${ }^{16}$ Overall, the included policies aimed to address three key areas relevant to this point: strengthening health systems to respond to NCDs, improving service delivery for citizens and improving population health. Similarly, the specific strategies outlined to achieve these aims focused on system strengthening, service delivery and a suite of general principles for NCD prevention/ management (taking a life course approach, establishment of cross-sectoral partnerships, and systems and services support for healthy behaviours and environments). Our meta-synthesis of evidence in this context aligns with the relatively recent WHO Framework on Integrated People-Centred Health Services (IPCHS) ${ }^{85}$ and advocacy efforts in promoting NCD control as a component of universal health coverage ${ }^{86}$ The derived specific actions (first-order codes) also mirror those of the WHO recommended interventions, or 'Best Buys', for NCD prevention and management. ${ }^{27}$ For example, the included policies focused strongly on interventions for physical activity and healthy behaviours and lifestyle choices relating to nutrition, enhancing activity levels and minimising substance abuse (alcohol and tobacco). The synergy between our data and these WHO frameworks suggest a policy shift from curative and hospital-centred biomedical care towards the delivery of integrated longterm health and social care for people who live with, or are at risk of, chronic and frequently comorbid NCDs. Our data also support the implementation strategies and priorities outlined in the WHO Integrated Care for Older People approach (a flagship programme of the Global Strategy and Action Plan on Ageing and Health that identifies musculoskeletal health as a key component of intrinsic capacity and necessary for healthy ageing) and the Rehabilitation 2030 agenda. ${ }^{23} 247$

Notably, only $19 \%$ of policies specifically referred to addressing healthy ageing. This may suggest a deprioritisation of ageing in the context of NCD care, that ageing policy is independent of NCD care for most countries, or that implementation of the Global Strategy and Action Plan for Ageing and Health will take some time to have an enduring influence on national policy. ${ }^{24}$ Nonetheless, the 2020-2030 Decade of Healthy Ageing is likely to be a catalyst for driving the evolution of healthy ageing policy in NCD care. Of note, few policies specifically addressed multimorbidity explicitly. Although multimorbidity may be implicitly addressed among policies focusing on 'all' NCDs, and also through strategies that are not disease-specific (eg, health promotion, improving access, integrated care), the absence of an explicit focus on multimorbidity collides with the prevalence of NCD multimorbidity, particularly that associated with ageing. ${ }^{88} 89$ This suggests a policy vacuum and potential system capacity gap in this critical area of health burden. ${ }^{90}$

\section{Musculoskeletal health in a broader NCD context}

Despite unequivocal evidence of the global burden imposed by impaired musculoskeletal health and pain, ${ }^{91}$ historically, these health states have not featured within policy and strategy in the context of prevention/ management for NCDs in high-income countries and LMICs. ${ }^{111692}$ Further, they are not included in the WHO NCD monitoring activities apart from the WHO European Region NCD plan. ${ }^{93}$ Although our data suggest that only half of the countries specifically identified musculoskeletal health or persistent pain as lying within the scope of their policies, this proportion nonetheless highlights recognition of, and in some cases, planned action towards improving the musculoskeletal health of populations in OECD countries.

Evidence from our meta-synthesis points to the need for system-level (macro) and service-level (meso) strengthening in NCD prevention and management, underpinned by a person-centred and life course approach. Prominent foci included health promotion (including healthy behaviours and environments, education, and early intervention, self-management) and monitoring; optimising service access and delivery including support for leveraging digital technologies, integrated and coordinated care, high-value interventions and workforce capacity building; and the formulation of appropriate policy, regulation and financing models-aligned to the WHO IPCHS framework. ${ }^{85}$ Although only $50 \%$ of countries specifically identified musculoskeletal health or pain as within the scope of included policies, and only $17 \%$ of countries had policies that covered 'all' NCDs (implicitly including musculoskeletal health), these foci are relevant across NCDs. Further, these foci typically feature as priority areas in contemporary models of care for musculoskeletal health and pain. ${ }^{94}{ }^{95}$ As highlighted in table 3, a range of musculoskeletal-specific strategies 
were identified that also align with these broader domains suggesting that effective prevention and management of musculoskeletal conditions could be achieved through policy implementation in countries without an explicit policy focus on these conditions. However, multiple factors will limit this progress, including: the current landscape of constrained fiscal healthcare resources, the widespread delivery of low-value care for musculoskeletal health conditions, ${ }^{96-99}$ the alignment of health monitoring and investment with the WHO NCD monitoring framework that excludes musculoskeletal health, the target for SDG 3.4 focusing on mortality reduction alone, and generally slow progress in achieving NCD targets. ${ }^{6}$ Meaningful population health gains in musculoskeletal health and pain outcomes may be limited until these health states are explicitly integrated into national policy, programme and financing models for NCD prevention and management, and into the WHO NCD monitoring framework. ${ }^{11}$ Further, it will remain essential to measure population health states, communicate the health and economic burden and national development threats imposed by musculoskeletal conditions, and support scalable system reform initiatives for musculoskeletal health conditions. ${ }^{11} 949699100$

\section{Policy implementation}

The majority of evaluated policies did outline implementation information. There was a strong focus on cross-sectoral agencies as providing joint responsibility for implementation, with less emphasis on specific details relating to timelines, prioritisation of initiatives and financing arrangements. These findings likely relate to the scope of the policies, the majority of which were focused on a whole-of-system reform agenda, rather than specific operational plans.

\section{Strengths, limitations and future directions}

The strengths of this research lay in the application of a standardised approach to reviewing and evaluating internal validity of the included policies using a multilingual research team, undertaking a comprehensive content analysis and deriving a meta-synthesis of the rich data with minimal discordance evident between reviewers. This analysis could be used as a model to prospectively monitor NCD policy evolution with a more specific focus on musculoskeletal health. For example, the current Norwegian NCD policy focuses on cardiovascular disease, diabetes, chronic obstructive pulmonary disease and cancer, while the planned update of that policy suggests a strong focus on musculoskeletal health (https://www.regjeringen.no/no/dokumenter/meld.st.-19-20182019/id2639770/sec3\#KAP6-1-1). We recognise that many countries have developed and implemented system-level disease-specific policies and frameworks (eg, models of care, strategies or care pathways), including those for musculoskeletal conditions. ${ }^{94} 95$ We did not evaluate these disease-specific policies, since we primarily sought to identify the extent of integration of musculoskeletal health within a broader policy framework for the prevention and management of NCDs.

The findings in this review should be interpreted in the context of some important limitations. First, our data are limited to policies submitted by OECD Member States in response to periodic NCD Country Capacity Surveys undertaken by the WHO. While this approach ensured that we accessed the most relevant policies as determined by the individual Member States, thereby providing a level of standardisation in document selection and minimising potential selection bias, it did preclude the inclusion of other potentially relevant policies, especially for the countries excluded from this review. Second, our data relied on the interpretations of reviewers who performed the data extractions and may therefore be subject to reviewer bias and variance. We attempted to minimise these threats through reviewer briefings, development of a protocol, inter-rater reliability testing of the data extraction tool, and quality checks of each submission received from the review team. Third, our scope was limited to OECD Member States. Therefore, the findings and implications are limited to predominantly high-income nations, with a disproportionate representation of European countries. In order to derive a broader and representative global profile of policy capacity in integrated NCD prevention and management (including musculoskeletal health), it would be important to extend the analysis to policies from LMICs and other non-OECD Member States. It would also be informative to repeat the analysis in 3-5 years, when revised policies are submitted by OCED Member States to assess policy evolution. In the longer term, evaluating the impact of policy change on musculoskeletal health outcomes, such as burden of disease, will be important.

\section{Author affiliations}

${ }^{1}$ School of Physiotherapy and Exercise Science, Curtin University, Perth, Western Australia, Australia

${ }^{2}$ Arthritis and Osteoporosis Western Australia, Perth, Western Australia, Australia ${ }^{3}$ Department of Health, Government of Western Australia, Perth, Western Australia, Australia

${ }^{4}$ Department of Surgery, St Vincent's Hospital (Melbourne), The University of Melbourne, Melbourne, Victoria, Australia

${ }^{5}$ Department of Physiotherapy, Sir Charles Gairdner Hospital, Perth, Western Australia, Australia

${ }^{6}$ Faculty of Business Management and Social Sciences, Hochschule Osnabrück, University of Applied Sciences, Osnabrück, Germany

${ }^{7}$ Department of Ageing and Lifecourse, World Health Organization, Geneva,

Switzerland

${ }^{8}$ Kanagawa Prefectural Government, Yokohama, , Japan

${ }^{9}$ The Institute of Health and Society, University of Oslo, Oslo, Norway

${ }^{10}$ Faculty of Science, University of Ottawa, Ottawa, Ontario, Canada

${ }^{11}$ European Cancer Patient Coalition, Brussels, Belgium

${ }^{12}$ UniTs, Universita' del Terzo Settore, Pisa, Italy

${ }^{13}$ Sjúkrapjálfun Kópavogs, Kópavogur, Iceland

${ }^{14}$ Twinkle English Academy, Seoul, Republic of Korea

${ }^{15}$ Medical School, University of Pécs, Pécs, Hungary

${ }^{16}$ Zsigmondy Vilmos Spa and Balneological Hospital of Harkány, Harkány, Hungary

Contributors $A M B$ and $H S$ conceived the study, planned the methods and led the work; AMB and HS procured funding; AMB, JGP, MLD, SB, BT, YS, OA, EMGH, $\mathrm{AC}, \mathrm{TH}, \mathrm{SR}, \mathrm{MP}$ and HS undertook data collection; AMB, JGP, MLD, EMGH and HS undertook data analysis; AMB, JGP, MLD, SB, BT, YS, OA, EMGH, AC, TH, SR, MP 
and $\mathrm{HS}$ contributed to interpretation of the data; AMB drafted the manuscript; AMB, JGP, MLD, SB, BT, YS, OA, EMGH, AC, TH, SR, MP and HS edited the manuscript and approved the final version.

Funding Funding to support the research was provided by the Department of Health, Government of Western Australia (Grant DoH20182446). AMB was supported by a Fellowship awarded by the Australian National Health and Medical Research Council (1132548).

Competing interests AMB reports grants from Department of Health, Government of Western Australia, grants from the Australian National Health and Medical Research Council, during the conduct of the study; personal fees from Department of Health, Government of Western Australia, personal fees from WHO, outside the submitted work; SB reports personal fees from Curtin University, during the conduct of the study. EMGH reports personal fees from Curtin University, grants from Mitacs Globalink Research Award, during the conduct of the study. SR reports personal fees from Curtin University, during the conduct of the study. HS reports grants from the Department of Health, Government of Western Australia during the conduct of the study.

\section{Patient consent for publication Not required.}

Provenance and peer review Not commissioned; externally peer reviewed.

Data availability statement All relevant data are reported in the paper

Open access This is an open access article distributed in accordance with the Creative Commons Attribution Non Commercial (CC BY-NC 4.0) license, which permits others to distribute, remix, adapt, build upon this work non-commercially, and license their derivative works on different terms, provided the original work is properly cited, appropriate credit is given, any changes made indicated, and the use is non-commercial. See: http://creativecommons.org/licenses/by-nc/4.0/.

\section{REFERENCES}

1. Saha A, Alleyne G. Recognizing noncommunicable diseases as a global health security threat. Bull World Health Organ 2018;96:792-3.

2. Jamison DT, Summers LH, Alleyne G, et al. Global health 2035: a world converging within a generation. The Lancet 2013;382:1898-955.

3. Nugent R, Bertram MY, Jan S, et al. Investing in non-communicable disease prevention and management to advance the sustainable development goals. The Lancet 2018;391:2029-35.

4. Kyu HH, Abate D, Abate $\mathrm{KH}$, et al. Global, regional, and national disability-adjusted life-years (DALYs) for 359 diseases and injuries and healthy life expectancy (HALE) for 195 countries and territories, 1990-2017: a systematic analysis for the global burden of disease study 2017. The Lancet 2018;392:1859-922.

5. Niessen LW, Mohan D, Akuoku JK, et al. Tackling socioeconomic inequalities and non-communicable diseases in low-income and middle-income countries under the sustainable development agenda. The Lancet 2018;391:2036-46.

6. World Health Organization. Time to deliver: report of the who independent high-level Commission on noncommunicable diseases. Geneva: WHO, 2018.

7. Kieny MP, Bekedam H, Dovlo D, et al. Strengthening health systems for universal health coverage and sustainable development. Bull World Health Organ 2017;95:537-9

8. Muka T, Imo D, Jaspers L, et al. The global impact of noncommunicable diseases on healthcare spending and national income: a systematic review. Eur J Epidemiol 2015;30:251-77.

9. James SL, Abate D, Abate $\mathrm{KH}$, et al. Global, regional, and national incidence, prevalence, and years lived with disability for 354 diseases and injuries for 195 countries and territories, 1990-2017: a systematic analysis for the global burden of disease study 2017. The Lancet 2018;392:1789-858.

10. Roth $\mathrm{GA}$, Abate $\mathrm{D}$, Abate $\mathrm{KH}$, et al. Global, regional, and national age-sex-specific mortality for 282 causes of death in 195 countries and territories, 1980-2017: a systematic analysis for the global burden of disease study 2017. The Lancet 2018;392:1736-88.

11. Briggs $A M$, Woolf $A D$, Dreinhöfer $K$, et al. Reducing the global burden of musculoskeletal conditions. Bull World Health Organ 2018:96:366-8.

12. Blyth FM, Briggs AM, Schneider $\mathrm{CH}$, et al. The global burden of musculoskeletal pain. Where to from here? Am J Public Health 2019;109:35-40.

13. Fayaz A, Croft P, Langford RM, et al. Prevalence of chronic pain in the UK: a systematic review and meta-analysis of population studies. BMJ Open 2016;6:e010364.
14. Jackson T, Thomas S, Stabile V, et al. A systematic review and meta-analysis of the global burden of chronic pain without clear etiology in low and middle-income countries: trends in heterogeneous data and a proposal for new assessment methods. Anesthesia Analgesia 2016;123:739-48.

15. Woolf AD, Pfleger B. Burden of major musculoskeletal conditions. Bull World Health Organ 2003;81:646-56.

16. Hoy D, Geere J-A, Davatchi F, et al. A time for action: opportunities for preventing the growing burden and disability from musculoskeletal conditions in low- and middle-income countries. Best Pract Res Clin Rheumatol 2014;28:377-93.

17. Atun R, Jaffar S, Nishtar S, et al. Improving responsiveness of health systems to non-communicable diseases. The Lancet 2013;381:690-7.

18. Araujo de Carvalho I, Epping-Jordan J, Pot AM, et al. Organizing integrated health-care services to meet older people's needs. Bull World Health Organ 2017;95:756-63.

19. World Health Organisation. World report on ageing and health. Geneva: WHO, 2015

20. United Nations and World Health Organization. Time to deliver. Third UN high-level meeting on non-communicable diseases. Geneva WHO; 2018.

21. World Health Organisation. Global action plan for the prevention and control of noncommunicable diseases 2013-2020. Geneva: WHO, 2013

22. World Health Organization. Assessing national capacity for the prevention and control of noncommunicable diseases: report of the 2017 global survey. Geneva: WHO, 2018.

23. Briggs AM, Araujo de Carvalho I, Carvalho Ade I. Actions required to implement integrated care for older people in the community using the world Health organization's ICOPE approach: a global Delphi consensus study. PLoS One 2018;13:e0205533.

24. World Health Organisation. Global strategy and action plan on ageing and health. Geneva: WHO, 2016.

25. World Health Organization. WHO global strategy on integrated people-centred health services 2016-2026. Geneva WHO; 2015

26. Barnett K, Mercer SW, Norbury M, et al. Epidemiology of multimorbidity and implications for health care, research, and medical education: a cross-sectional study. The Lancet 2012;380:37-43.

27. World Health Organization. Tackling NCDs: 'Best buys' and other recommended interventions for the prevention and control of noncommunicable diseases. Geneva WHO; 2017.

28. Adebiyi BO, Mukumbang FC, Beytell A-M. To what extent is Fetal Alcohol Spectrum Disorder considered in policy-related documents in South Africa? A document review. Health Res Policy Sys 2019;17.

29. Bundesministerium für Gesundh. Nationaler Aktionsplan Ernährung Wien: Bundesministerium für Gesundheit, 2013.

30. Bundesministerium für Landesverteidigung und Sport und Bundesministerium für Gesundheit. Nationaler Aktionsplan Bewegung. Wien: Bundesministerium für Landesverteidigung und Sport, 2013

31. Cheung KK, Mirzaei M, Leeder S. Health policy analysis: a tool to evaluate in policy documents the alignment between policy statements and intended outcomes. Aust. Health Review 2010;34:405-13.

32. Briggs AM, Jordan JE, Jennings $M$, et al. Supporting the evaluation and implementation of musculoskeletal models of care: a globally informed framework for judging readiness and success. Arthritis Care Res 2017;69:567-77.

33. Mahimbo A, Seale H, Heywood AE. Immunisation for refugees in Australia: a policy review and analysis across all states and territories. Aust N Z J Public Health 2017;41:635-40.

34. Fleiss JL. Measuring nominal scale agreement among many raters. Psychol Bull 1971;76:378-82.

35. Hsieh H-F, Shannon SE. Three approaches to qualitative content analysis. Qual Health Res 2005;15:1277-88.

36. Cunningham M, Wells M. Qualitative analysis of 6961 free-text comments from the first National cancer patient experience survey in Scotland. BMJ Open 2017;7:e015726.

37. Briggs AM, Houlding E, Hinman RS, et al. Health professionals and students encounter multi-level barriers to implementing highvalue osteoarthritis care: a multi-national study. Osteoarthritis and Cartilage 2019;27:788-804.

38. Governo de Saúde. Plano Nacional de Saúde Revisão e Estensão a 2020. Lisboa Governo de Portugal; 2015.

39. Republic of Turkey Ministry of Health. Multisectoral Action Plan of Turkey for Noncommunicable Diseases 2017-2025. Ankara Republic of Turkey; 2017. 
40. 보건복지부. 제3차 국민건강증진종합계획 (2011-2020). 서울 보건복지부; 2011.

41. Health Canada. Canada's Tobacco Strategy. Ottawa: Government of Canada, 2018.

42. Public Health Agency of Canada. Curbing Childhood Obesity: A Federal, Provincial and Territorial Framework for Action to Promote Healthy Weights. Ottawa: Government of Canada, 2010.

43. Public Health Agency of Canada. Let's get moving: A common vision for increasing physical activity and reducing sedentary living in Canada. Ottawa: Government of Canada, 2018.

44. Public Health Agency of Canada. Integrated Strategy on Healthy Living and Chronic Disease. Ottawa: Government of Canada, 2005.

45. Australian Health Ministers' Advisory Council. National Strategic Framework for Chronic Conditions. Canberra: Australian Government, 2017.

46. Santé publique, Sécurité de la Chaîne alimentaire et Environnement. Plan conjoint en faveur des malades chroniques. Des soins intégrés pour une meilleure santé. Bruxelles: Service Publique Fédéral Belgique, 2015.

47. Gobierno de Chile. Estrategia Nacional de Salud para el cumplimiento de los Objectivos Sanitarios de la Década. Santiago: Gobierno de Chile, 2011.

48. Ministry of Health of the Czech Republic in cooperation with the National Institute of Public Health. HEALTH 2020: National Strategy for Health Protection and Promotion and Disease Prevention. Prague: Government of the Czech Republic, 2014.

49. Ministerstvo zdravotnictví ČR. Dlouhodobý program zlepšování zdravotniho stavu obyvatelstva ČR -Zdraví pro všechny V 21. století. Praha: Vládou České Republiky, 2002.

50. Sundhedsstyrelsen. Anbefalinger for forebyggelsestilbud til borgere med kronisk sygdom. København, 2016.

51. Sundhedsstyrelsen. Forløbsprogrammer for kronisk sygdom - den generiske model. København: Danmarks regering, 2012.

52. Ministry of Social Affairs. National Health Plan 2009-2020. Tallinn: Republic of Estonia, 2012.

53. L'Assemblé national et le Sénat. Journal officiel de la République française No 22 du 27 janvier 2016: Loi no 2016-41 du 26 janvier 2016 de modernisation de notre système de santé (1) Titre Liminaire: Rassembler les acteurs de la santé autour d'une stratégie partagée. Paris: République Française, 2016.

54. Ministère des affaires sociales et de la santé. Stratégie Nationale de Santé : Feuille de Route. Paris: République Française, 2013.

55. Bundesministerium für Ernährung und Landwirtschaft (BMEL), Bundesministerium für Gesundheit. IN FORM: Deutschlands initiative für gesunde Ernährung und mehr Bewegung Nationaler Aktionsplan zur Prävention von Fehlernährung, Bewegungsmangel, Übergewicht und damit zusammenhängenden Krankheiten. Berlin: Bundesregierung, 2014

56. Emberi Erőforrások Minisztériuma. Magyarország kormánya. “Egészséges Magyarország 2014-2020” - Egészségügyi Ágazati Stratégia. 2015. Budapest: Magyarország kormánya.

57. Velferðarráđuneytið. Lýðheilsustefna og aðgerðir sem stuðla að̛ heilsueflandi samfélagi - með sérstakri áherslu á börn og ungmenni að 18 ára aldri. Reykjavík: Ríkisskrifstofur lýðveldisins Íslands, 2016.

58. Department of Health \& Children. A Policy Framework for the Management of Chronic Disease. Dublin: The Republic of Ireland, 2008.

59. Department of Health. Healthy Ireland: A Framework for Improved Health and Wellbeing 2013 -2025. Dublin: The Republic of Ireland, 2013.

60. Ministero della Salute. Piano Nazionale della Prevenzione 20142018. Roma: Governo d'italia, 2014.

61. Ministero della Salute, Direzione Generale della Programmazione Sanitaria. Piano Nazionale della Cronicità. Governo d'italia: Roma, 2016.

62. Ministero della Salute, Dipartimento della Prevenzione e Comunicazione. GUADAGNARE SALUTE: Rendere facili le scelte salutari. Roma: Governo d'italia, 2008.

63. 厚生労働省. 健康日本21 (第二次). 東京 日本政府; 2012.

64. Korean Ministry of Health and Welfare. National Health Plan 2020 in Korea. Seoul: Korea Health Promotion Foundation, 2011.

65. Ministru kabineta. Sabiedrības veselības pamatnostādnes 2014.2020. gadam. Ryga: Latvijos Respublika, 2014.

66. Ministry of Health. Seimas of the Republic of Lithuania Resolution No XII-964 of Approval of the Lithuanian Health Strategy 20142025. Vilnius: Seimas of the Republic of Lithuania, 2014

67. Lietuvos Respublikos Vyriausybè. Dè 20142020 metu nacionalinès pažangos programos horizontaliojo prioriteto „Sveikata visiems "tarpinstitucinio veiklos plano patvirtinimo. Vilnius: Lietuvos Respublikos Seimas, 2014.
68. Government of the Republic of Lithuania. Resolution No. 1291 on approval of the National public health care development programme for 2016-2023. Vilnius: Government of the Republic of Lithuania, 2015.

69. Gobierno de la República de México. Estrategia Nacional para la Prevención y el Control del Sobrepeso, la Obesidad y la Diabetes. Gobierno de la República de México: Ciudad de México, 2013.

70. Government of the Netherlands. All About Health. The National Prevention Program 2014-2016. Amsterdam: Government of the Netherlands, 2013.

71. Norwegian Ministry of Health and Care Services. NCD-Strategy 2013-2017. For the prevention, diagnosis, treatment and rehabilitation of four noncommunicable diseases: cardiovascular disease, diabetes, COPD and cancer. Oslo: Government of Norway, 2013.

72. Rada ministrów. W sprawie Narodowego Programu Zdrowia na lata 2016-2020. Warszawa: Rzeczypospolirej Polskiej, 2016.

73. Úrad verejného zdravotníctva Slovenskej republiky. Aktualizácia Národného programu podpory zdravia v Slovenskej republike. Bratysława: Republika Słowacji, 2014.

74. National Assembly of the Republic of Slovenia. Resolution on National Health Care Plan 2016-202. Ljubljana: Government of the Republic of Slovenia, 2016.

75. Misterio de Sandidad, Servicios Sociales e Igualdad. Estrategia para el Abordaje de la Cronicidad en el Sistema Nacional de Salud. Madrid: Gobierno de España, 2012.

76. Socialdepartementet. En folkhälsopolitik Med människan i centrum. Stockholm: Sveriges regeringskontor, 2012.

77. Ministry of Health and Social Affairs. A cohesive strategy for alcohol, narcotic drugs, doping and tobacco (ANDT) policy. A summarised version of government bill 2010/11:47. Stockholm: Ministry of Health and Social Affairs, Sweden, 2011.

78. Bundesamt für Gesundheit (BAG) und Schweizerische Konferenz der kantonalen Gesundheitsdirektorinnen und -direktoren (GDK) und Gesundheitsförderung Schweiz. Massnahmenplan zur Nationalen Strategie Prävention nichtübertragbarer Krankheiten (NCD-Strategie) 2017-2024. Bern: Die schweizer Regierung, 2016

79. Bundesamt für Gesundheit (BAG) und Schweizerische Konferenz der kantonalen Gesundheitsdirektorinnen und -direktoren (GDK). Nationale Strategie Prävention nichtübertragbarer Krankheiten (NCD-Strategie), 2017-2024. Bern: Die schweizer Regierung, 2016.

80. Public Health Policy \& Strategy Unit/NHS Commissioning Unit. $A$ Call to Action to Reduce Avoidable Premature Mortality. London: Department of Health and Social Care, 2013.

81. National Prevention, Health Promotion, and Public Health Council. National Prevention Council Action Plan: Implementing the National Prevention Strategy. Washington D.C: Office of the Surgeon General, U.S. Public Health Service, 2012.

82. World Health Organization. Everybody business: Strengthening health systems to improve health outcomes. WHO's framework for action. Geneva: WHO, 2007.

83. NCD Alliance. Shaping the health systems of the future. Case studies and recommendations for integrated ncd care. Geneva: NCD Alliance, 2018.

84. Samb B, Desai N, Nishtar S, et al. Prevention and management of chronic disease: a litmus test for health-systems strengthening in low-income and middle-income countries. The Lancet 2010;376:1785-97.

85. World Health Organization. Framework on integrated, peoplecentred health services. Geneva: WHO, 2016.

86. NCD Alliance. NCA Alliance Advocacy Priorities. The 2019 United Nations High-Level Meeting on Universal Health Coverage. Geneva: NCD Alliance, 2019.

87. World Health Organisation. Rehabilitation in health systems. Geneva: WHO, 2017.

88. Afshar S, Roderick PJ, Kowal P, et al. Multimorbidity and the inequalities of global ageing: a cross-sectional study of 28 countries using the world health surveys. BMC Public Health 2015;15:776.

89. Marengoni A, Angleman S, Melis R, et al. Aging with multimorbidity: a systematic review of the literature. Ageing Res Rev 2011;10:430-9.

90. Atun R. Transitioning health systems for multimorbidity. The Lancet 2015;386:721-2.

91. Rice ASC, Smith BH, Blyth FM. Pain and the global burden of disease. Pain 2016:157:791-6.

92. Blyth FM, Huckel Schneider C. Global burden of pain and global pain policy-creating a purposeful body of evidence. Pain 2018;159(Suppl 1):S43-S48.

93. World Health Organization Regional Office for Europe. Action plan for the prevention and control of noncommunicable diseases in 
the WHO European region. Copenhagen: WHO Regional Office for Europe, 2016.

94. Briggs AM, Chan M, Slater H. Models of care for musculoskeletal health: moving towards meaningful implementation and evaluation across conditions and care settings. Best Pract Res Clin Rheumatol 2016;30:359-74.

95. Speerin R, Slater H, Li L, et al. Moving from evidence to practice: models of care for the prevention and management of musculoskeletal conditions. Best Pract Res Clin Rheumatol 2014;28:479-515.

96. Briggs AM, Slater $\mathrm{H}$, Hsieh E, et al. System strengthening to support value-based care and healthy ageing for people with chronic pain. Pain 2019;160:1240-4.
97. Foster NE, Anema JR, Cherkin D, et al. Prevention and treatment of low back pain: evidence, challenges, and promising directions. The Lancet 2018;391:2368-83.

98. Elshaug AG, Watt AM, Mundy L, et al. Over 150 potentially low-value health care practices: an Australian study. Med J Aust 2012;197:556-60.

99. Traeger AC, Buchbinder R, Elshaug AG, et al. Care for low back pain: can health systems deliver? Bull World Health Organ 2019;97:423-33.

100. Briggs AM, Cross MJ, Hoy DG, et al. Musculoskeletal health conditions represent a global threat to healthy aging: a report for the 2015 World Health organization world report on ageing and health. Gerontologist 2016;56(Suppl 2):S243-S255. 